\title{
SUBJECT MATTER JURISDICTION: THE NOTION OF INVESTMENT
}

\section{Michael Waibel}

I. Introduction

II. The Objective versus Subjective Controversy over the Meaning of Investment

A. The trend towards an objective meaning in the practice of investment tribunals

B. Evolving the meaning of investment through interpretation

C. The inconclusive travaux préparatoires on the definition of investment

III. The Objective Elements of Investments

A. Objective elements of investments in the negotiations of the ICSID Convention

B. The Salini criteria and their critics 46

i. Contribution $\quad 52$

ii. Duration $\quad 56$

iii. Risk 56

iv. (Contribution to the) economic development of the host State 58

$\begin{array}{ll}\text { v. Profit and return } & 60\end{array}$

vi. Territoriality 60

vii. Investments in accordance with the laws of the host State or good faith investments

C. The new objectivism: objective in name only

D. The commercial transaction test: distinguishing investments from commercial transactions

E. Elements of investments in ICSID Additional Facility, UNCITRAL or SCC cases

B. Arbitral awards and judgments as investments $\quad 75$

$\begin{array}{ll}\text { i. Commercial arbitral awards } & 75\end{array}$ 
ii. Investment arbitral awards $\quad 77$

iii. Judgments of national courts in the host country 77

V. Conclusion

Appendix: Lists of cases covered in this study

\section{INTRODUCTION}

1. The subject of this volume of the ICSID Reports is the notion of "investment"the crucial touchstone of the subject matter jurisdiction of ICSID tribunals. As is well known, the ICSID Convention does not define what "investments" are. Article 25 ICSID Convention, the only provision on the subject matter jurisdiction of ICSID tribunals, merely refers to "investment". Investment tribunals and the literature have adopted divergent approaches with respect to two specific features of the term "investment". These two features are: (i) whether "investment" in Article 25 ICSID Convention has an objective meaning, in addition to the definition of investment in the instrument of consent/the investment treaty (the controversy over the objective versus subjective meaning of investment); and (ii) if "investment" has an objective meaning, which elements ought to be used to objectively determine investments (the controversy about objective or characteristic elements of investments). Specifically, there has been some controversy as to whether an objective element is that the transaction contributes to the host country's economic development.

2. This study explores both features. It focuses on the second feature because the objective elements that may characterise investments have considerable practical relevance for the jurisdictional determinations of ICSID tribunals. Section II analyses whether "investment" in Article 25 ICSID Convention has an objective meaning, and whether the term "investment" has evolved over time. Section III examines possible objective elements of investments. Section IV considers two special cases whose investment status is unclear considering these two controversies: first, whether financial instruments qualify as investments and, second, whether commercial arbitration awards, investment awards or judgments by national courts in the host country qualify as investments.

\section{THE OBJECTIVE VERSUS SUBJECTIVE CONTROVERSY OVER THE MEANING OF INVESTMENT}

3. The controversy over the objective or subjective meaning of investment that is the subject of this Section concerns the implications of the ICSID Convention's failure to define investment: does it mean that Article 25 ICSID Convention does not limit which transactions count as investments (subjective meaning), leaving this definition entirely to the instrument of consent; or do certain transactions not qualify as investments because they do not exhibit characteristic features of investments (objective meaning)? 
4. A first group of tribunals uses the failure of the delegates who negotiated the ICSID Convention to define investment in support of the conclusion that Article 25 ICSID Convention refers to an objective meaning of investment, or at least an objective core of investment. By contrast, a second group of tribunals considers that the absence of a definition means that there is no objective definition of investment. Accordingly, the silence in Article 25 ICSID Convention shifts the exclusive focus to the instrument of consent, to which alone the definition of investment is left: the investment contract, the domestic investment statute or the investment treaty. The definitions of "investments" in investment statutes and treaties strongly resemble each other. ${ }^{1}$

5. Views in the literature on the definition of investment in Article 25 ICSID Convention divide along similar lines. ${ }^{2}$ A first school of thought holds that the silence in Article 25 ICSID Convention on the definition of investment is a simple silence, an unintended gap, which does not warrant extensive interpretation as a matter of course. ${ }^{3}$ A second school of thought holds that the silence is qualified (or strategic) such that there is no gap - the drafters of the ICSID Convention deliberately left the term undefined and delegated the definition of investment to future decision-makers (the drafters of the instrument of consent and/or investment tribunals) - prompting some tribunals to interpret the term "investment" broadly. ${ }^{4}$

1 J. Hepburn, "Domestic Investment Statutes in International Law" (2018) 112 American Journal of International Law 658, 658. A domestic investment statute (the 1994 Kazakh Law on Foreign Investment) provided the basis for the tribunal's jurisdiction in only one of the awards reported in this volume, namely AES Corporation and Tau Power BV v. Republic of Kazakhstan, ICSID Case No. ARB/10/16, Award (1 November 2013) [AES v. Kazakhstan]. The investment concerned power plants and trading companies with long-term concessions for managing power distribution.

2 E. Gaillard, "Identify or Define? Reflections on the Evolution of the Concept of Investment in ICSID Practice", in C. Binder, U. Kriebaum, A. Reinisch and S. Wittich (eds.), International Investment Law for the 21st Century: Essays in Honour of Christoph Schreuer (Oxford University Press, 2009), 403-16 (referring to the "intentional" absence of a definition, and distinguishing between the "intuitive" (subjective) and the "deductive" (objective) method for determining investments). Compare J. D. Mortenson, "The Meaning of "Investment": ICSID's Travaux and the Domain of International Investment Law" (2010) 51 Harvard International Law Journal 257, 280-94 (favouring wide-open jurisdiction) with M. Waibel, "Opening Pandora's Box: Sovereign Bonds in International Arbitration" (2007) 101 American Journal of International Law 711, 718-32 (favouring outer limits of "investment").

3 S. Wordsworth, "Investment Arbitration: Mass Claims" (2014) 8 World Arbitration and Mediation Review 332, 336 (with respect to mass claims); Abaclat and Others (Case Formerly Known as Giovanna a Beccara and Others) v. Argentine Republic, ICSID Case No. ARB/07/5, Decision on Jurisdiction and Admissibility (4 August 2011) [Abaclat v. Argentina], paras. 524-7. Cf. also the discussion in R. Kabra, "Jurisdictional Aspects of Multiparty Actions in International Dispute Settlement" (PhD thesis, University of Cambridge 2019), 135-42.

4 E.g. Ambiente Ufficio SpA and Others v. Argentine Republic, ICSID Case No. ARB/08/9, Decision on Jurisdiction and Admissibility (8 February 2013) [Ambiente Ufficio v. Argentina], para. 454; T. Cole and A. K. Vaksha, "Power-Conferring Treaties: The Meaning of 'Investment' in the ICSID Convention" (2011) 24 Leiden Journal of International Law 305; P. Ortolani, "Are Bondholders Investors? Sovereign Debt and Investment Arbitration after Poštová" (2017) 30 Leiden Journal of International Law 383, 398-9; M. Sattorova "Defining Investment under the ICSID Convention and BITs: Of Ordinary Meaning, Telos, and Beyond" (2012) 2 Asian Journal of International Law 267, 279 (while arguably "the vehicles of ambiguity and silence were intended to moderate the scope of investment ... the open-ended definition can be exploited by advocates of expansive interpretation") and 281 (open-ended character as a deliberate choice). 
Accordingly, the absence of a definition of investment in Article 25 ICSID Convention means that the instrument of consent alone, usually an investment treaty in recent decades, defines what counts as an investment.

\section{A. The trend towards an objective meaning in the practice of investment tribunals}

6. Investment tribunals have increasingly accepted that the meaning of investment in Article 25 ICSID Convention is objective and cannot be varied by the two parties to a bilateral investment treaty. ${ }^{5}$ Even though a few tribunals continue to adhere to the "subjective" meaning of investment, ${ }^{6}$ an increasing line of decisions finds that Article 25 ICSID Convention contains an "objective" meaning of investment, ${ }^{7}$ including 12 of the 25 decisions summarised in this volume. ${ }^{8}$ Accordingly, ICSID tribunals assess whether a transaction falls within Article 25 ICSID Convention's own notion of "investment". Some regard Article 25 ICSID Convention as a device to prevent the floodgates to ICSID arbitration from being opened. ${ }^{9}$

5 Waibel, "Opening Pandora's Box", n. 2, 718-19.

6 S. W. Schill, "Article 25", in S. W. Schill, L. Malintoppi, A. Reinisch, C. H. Schreuer and A. Sinclair (eds.), Schreuer's Commentary on the ICSID Convention: A Commentary on the Convention on the Settlement of Investment Disputes between States and Nationals of Other States (Cambridge University Press, 3rd edn, 2021), para. 180, referring to ATA Construction, Industrial and Trading Company v. Hashemite Kingdom of Jordan, ICSID Case No. ARB/08/2, Award (18 May 2010) [ATA v. Jordan], para. 111; Adel A Hamadi Al Tamimi v. Sultanate of Oman, ICSID Case No. ARB/11/33, Award (3 November 2015), paras. 275-80; Garanti Koza LLP v. Turkmenistan, ICSID Case No. ARB/11/20, Award (19 December 2016), paras. 235-42; Tethyan Copper Company v. Pakistan, ICSID Case No. ARB/12/1, Decision on Jurisdiction and Liability (10 November 2017), para. 571.

7 Schill, "Article 25", n. 6, paras. 177-86.

8 Note, however, that only 15 of the 25 decisions address this question. In six awards, the ICSID Convention was not applicable or the tribunal's findings were limited to the investment treaty; i.e. the tribunal made no finding on Article 25 ICSID Convention. A few important awards on the notion of investment do not appear in this volume because they have already appeared in previous volumes of the ICSID Reports (see para. 9). Chronologically, the 12 awards are Mitchell v. Democratic Republic of the Congo, ICSID Case No. ARB/99/7, Decision on the Application for Annulment of the Award (1 November 2006) [Mitchell v. DRC Annulment]; Malaysian Historical Salvors Sdn, Bhd v. Malaysia, ICSID Case No. ARB/05/10, Award (28 May 2007) [Malaysian Historical Salvors v. Malaysia]; Phoenix Action, Ltd v. Czech Republic, ICSID Case No. ARB/06/5, Award (15 April 2009) [Phoenix Action v. Czech Republic]; Romak SA (Switzerland) v. The Republic of Uzbekistan, PCA Case No. AA280, Award (26 November 2009) [Romak v. Uzbekistan]; Mr Saba Fakes v. Republic of Turkey, ICSID Case No. ARB/07/20, Award (14 July 2010) [Fakes v. Turkey], paras. 108-9 (referring to Joy Mining v. Egypt, ICSID Case No. ARB/03/11, Award on Jurisdiction (6 August 2004) [Joy Mining v. Egypt], paras. 49-50); Global Trading Resource Corp. and Globex International, Inc. v. Ukraine, ICSID Case No. ARB/09/11, Award (1 December 2010) [Global Trading Resource v. Ukraine], paras. 43-5; Abaclat v. Argentina; Deutsche Bank AG v. Democratic Socialist Republic of Sri Lanka, ICSID Case No. ARB/09/2, Award (31 October 2012) [Deutsche Bank v. Sri Lanka]; Ambiente Ufficio v. Argentina; Poštová banka, a.s. and Istrokapital SE v. The Hellenic Republic, ICSID Case No. ARB/13/8, Award (9 April 2015) [Poštová banka v. Greece]; Marco Gavazzi and Stefano Gavazzi v. Romania, ICSID Case No. ARB/12/25, Decision on Jurisdiction, Admissibility and Liability (21 April 2015) [Gavazzi v. Romania]; MNSS BV and Recupero Credito Acciaio N.V. v. Montenegro, ICSID Case No. ARB(AF)/12/8, Award (4 May 2016) [MNSS v. Montenegro].

9 M. Hwang and J. Fong Lee Cheng, "Definition of 'Investment' - A Voice from the Eye of the Storm" (2011) 1 Asian Journal of International Law 99-129, 106 and 109-11 (discussing the "protective function" of Article 25 ICSID Convention). 
7. This approach is also known as the "outer limits" test, ${ }^{10}$ or a "doublebarrelled test". ${ }^{11}$ This is because tribunals assess, over and above the applicable investment treaty, whether the transaction qualifies as an investment under Article 25 ICSID Convention. The first leg (or barrel) is the investment treaty, whereas the second is Article 25 ICSID Convention. Accordingly, an investment treaty can restrict the subject matter scope of the ICSID Convention as regards the requirement of an investment but cannot expand it. ${ }^{12}$

8. Table 1 summarises the cases reported in this volume. For each of the 21 cases (column 1), organised by year of the decision or award in ascending order (column 2), Table 1 shows:

a. the economic activity that the investor contended amounted to an investment (column 3);

b. whether the tribunal affirmed or declined jurisdiction (column 4);

c. the applicable arbitration rules, other than the ICSID Arbitration Rules (column 5);

d. whether an arbitrator dissented on jurisdiction (column 6); and

e. whether an ad hoc annulment committee annulled the jurisdictional finding of the tribunal (column 7).

9. A few important awards on the notion of investment do not appear in this volume because they have already appeared in previous volumes of the ICSID Reports. ${ }^{13}$ Examples include Fedax v. Venezuela, ${ }^{14}$ Salini v. Morocco ${ }^{15}$ - the originator of the Salini criteria examined below - and Joy Mining v. Egypt. ${ }^{16}$

10. Whether there is a second barrel is significant because many investment treaties (mostly concluded in the 1990s and the 2000s) adopt a broad, asset-backed definition of investment with illustrative examples. This contrasts with the ICSID Convention of 1965. Depending on one's views, either the ICSID Convention adopted a narrower view of what constitutes investment than the one found in most investment treaties, or the Convention did not adopt any definition at all. ${ }^{17}$ Notably, investment treaties often include in their definition of investment

\footnotetext{
10 International Centre for Settlement of Investment Disputes, History of the ICSID Convention: Documents Concerning the Origin and the Formulation of the Convention on the Settlement of Investment Disputes between States and Nationals of Other States (1968), Vol. II-2, 700 [ICSID History Vol. II-2]. On the "outer limits" of foreign control in Article 25(2)(b) ICSID Convention, see Caratube International Oil Company LLP v. The Republic of Kazakhstan, ICSID Case No. ARB/08/12, Award (5 June 2012) [Caratube v. Kazakhstan], paras. 310-38.

${ }_{11}$ Phoenix Action v. Czech Republic, para. 74 (citing Malaysian Historical Salvors v. Malaysia, para. 55).

12 Phoenix Action v. Czech Republic, para. 96.

13 References to the relevant volumes of the ICSID Reports for each decision are provided in bold type in the Appendix to this study. See also the Table of cases reported in Volumes 1-19 (alphabetical) at p. xxvi.

14 Fedax N.V. v. Republic of Venezuela, ICSID Case No. ARB/96/3, Objections to Jurisdiction (11 July 1997) [Fedax v. Venezuela].

15 Salini Costruttori SpA and Italstrade SpA v. Kingdom of Morocco, ICSID Case No. ARB/00/4, Decision on Jurisdiction (16 July 2001).

16 Joy Mining v. Egypt. $\quad 17$ Schill, “Article 25”, n. 6, paras. 214-15.
} 
Table 1 Decisions of investment tribunals on the notion of investment

\begin{tabular}{|c|c|c|c|c|c|c|}
\hline Case & $\begin{array}{l}\text { Date of } \\
\text { Award }\end{array}$ & Economic activity (chronological) & $\begin{array}{l}\text { Subject matter } \\
\text { jurisdiction }\end{array}$ & Rules $^{\mathrm{i}}$ & Dissent $^{\mathrm{ii}}$ & Annulled \\
\hline Mitchell v. DRC & $\begin{array}{l}9 \text { February } \\
2004\end{array}$ & Legal services & Yes & & $\mathrm{x}$ & $\mathrm{x}$ \\
\hline $\begin{array}{l}\text { Malaysian Historical } \\
\text { Salvors v. Malaysia }\end{array}$ & 17 May 2007 & $\begin{array}{l}\text { Marine salvage of cargo from vessel in host } \\
\text { State's territorial waters }\end{array}$ & No & & $\begin{array}{l}\mathrm{X} \\
\text { (annulment) }\end{array}$ & $\mathrm{x}$ \\
\hline Bayview v. Mexico & 19 June 2007 & Water rights & No & $\begin{array}{l}\text { ICSID } \\
\text { Additional } \\
\text { Facility }\end{array}$ & & \\
\hline $\begin{array}{l}\text { Biwater Gauff } \\
\text { v. Tanzania }\end{array}$ & 24 July 2008 & Water supply and sanitation & Yes & & & \\
\hline $\begin{array}{l}\text { Quasar de Valors } \\
\text { v. Russia }\end{array}$ & $\begin{array}{l}20 \text { March } \\
2009\end{array}$ & Yukos' American Depository Receipts & Yes & SCC & & $\begin{array}{l}\text { Svea Court } \\
\text { of Appeal } \\
\text { set aside the } \\
\text { award }\end{array}$ \\
\hline $\begin{array}{l}\text { Phoenix Action } \\
\text { v. Czech Republic }\end{array}$ & 15 April 2009 & Ownership of two companies trading ferroalloys & No & & & \\
\hline Romak v. Uzbekistan & $\begin{array}{l}26 \text { November } \\
2009\end{array}$ & $\begin{array}{l}\text { Supply agreement of wheat; agreement to } \\
\text { provide data and recommendations on global } \\
\text { grain stocks; commercial arbitral award based } \\
\text { on supply agreement }\end{array}$ & No & UNCITRAL & & \\
\hline Fakes v. Turkey & 14 July 2010 & Purchase of shares & No & & & \\
\hline Global Trading & 1 December & Sale and purchase contract of poultry & No & & & \\
\hline Resource v. Ukraine & 2010 & & & & & \\
\hline HICEE v. Slovakia & 23 May 2011 & $\begin{array}{l}\text { Shares in operating companies owned via } \\
\text { intermediary of domestic holding company }\end{array}$ & No & UNCITRAL & $\mathrm{x}$ & \\
\hline Abaclat v. Argentina & $\begin{array}{l}4 \text { August } \\
2011\end{array}$ & Sovereign bonds & Yes & & $\mathrm{x}$ & \\
\hline Caratube v. Kazakhstan & 5 June 2012 & Purchase of shares & $\begin{array}{l}\text { Yes (but finding only } \\
\text { on BIT, not Article 25) }\end{array}$ & & & \\
\hline
\end{tabular}


Table 1 (cont.)

\begin{tabular}{|c|c|c|c|c|c|c|}
\hline Case & $\begin{array}{l}\text { Date of } \\
\text { Award }\end{array}$ & Economic activity (chronological) & $\begin{array}{l}\text { Subject matter } \\
\text { jurisdiction }\end{array}$ & Rules $^{\mathrm{i}}$ & Dissent $^{\mathrm{ii}}$ & Annulled \\
\hline Deutsche Bank v. Sri & 31 October & Oil hedging agreement & Yes & & $\mathrm{x}$ & \\
\hline Lanka & 2012 & & & & & \\
\hline Standard Chartered & 2 November & Debt owned by a subsidiary which is not a & No (but finding only & & & \\
\hline Bank v. Tanzania & 2012 & national of the BIT parties & on BIT, not Article 25) & & & \\
\hline Ambiente & 8 February & Sovereign bonds & Yes & & $\mathrm{x}$ & \\
\hline Ufficio v. Argentina & 2013 & & & & & \\
\hline AES v. Kazakhstan & $\begin{array}{l}1 \text { November } \\
2013\end{array}$ & $\begin{array}{l}\text { Shares in heat and power plants and trading } \\
\text { companies with concessions }\end{array}$ & $\begin{array}{l}\text { Investment character } \\
\text { undisputed }\end{array}$ & & & \\
\hline Enkev Beheer v. Poland & 29 April 2014 & $\begin{array}{l}\text { Majority shareholding in a local company } \\
\text { owning industrial facilities and a usufruct right } \\
\text { to land }\end{array}$ & $\begin{array}{l}\text { Yes (shares); no } \\
\text { (im/movable property, } \\
\text { retention of profits and } \\
\text { management of } \\
\text { subsidiary) }\end{array}$ & UNCITRAL & & \\
\hline Apotex v. USA & $\begin{array}{l}25 \text { August } \\
2014\end{array}$ & Drug imports & No & & & \\
\hline $\begin{array}{l}\text { Poštová } \\
\text { banka v. Greece }\end{array}$ & 9 April 2015 & Sovereign bonds & $\begin{array}{l}\text { No (under BIT), } \\
\text { No (Art. 25, 2:1, } \\
\text { obiter) }\end{array}$ & & $\mathrm{x}$ (obiter) & $\begin{array}{l}\text { Upheld in } \\
\text { annulment }\end{array}$ \\
\hline Gavazzi v. Romania & 21 April 2015 & $\begin{array}{l}\text { Purchase of shares; award compensating for } \\
\text { investment made }\end{array}$ & Yes & & & \\
\hline MNSS v. Montenegro & 4 May 2016 & Shares and loans & Yes & $\begin{array}{l}\text { ICSID } \\
\text { Additional } \\
\text { Facility }\end{array}$ & & \\
\hline
\end{tabular}

\footnotetext{
${ }^{\mathrm{i}}$ ICSID Arbitration Rules unless otherwise indicated.
}

ii Unanimous unless other indicated. 
"every kind of asset" and "claims to money"18 or "obligations" and "any right of an economic nature granted by law or by contract". ${ }^{19}$ Remarkably, the definitions of investment in some investment treaties are circular, ${ }^{20}$ or mix forms of investment with rights associated with them. ${ }^{21}$ The qualification of financial instruments as an investment by some tribunals illustrates the breadth of the typical definition found in investment treaties (see paras. 111-20 below).

11. Some investment treaties concluded in recent years expressly exclude certain transactions from the notion of investment. A good example is the "investment" definition in Article 8.1 of the EU-Canada Comprehensive Economic and Trade Agreement (CETA): ${ }^{22}$

investment means every kind of asset that an investor owns or controls, directly or indirectly, that has the characteristics of an investment, which includes a certain duration and other characteristics such as the commitment of capital or other resources, the expectation of gain or profit, or the assumption of risk. Forms that an investment may take include:

(a) an enterprise;

(b) shares, stocks and other forms of equity participation in an enterprise;

(c) bonds, debentures and other debt instruments of an enterprise;

(d) a loan to an enterprise;

(e) any other kind of interest in an enterprise;

(f) an interest arising from:

(i) a concession conferred pursuant to the law of a Party or under a contract, including to search for, cultivate, extract or exploit natural resources,

(ii) a turnkey, construction, production or revenue-sharing contract; or

(iii) other similar contracts;

18 E.g. Treaty between the Federal Republic of Germany and the Democratic Socialist Republic of Sri Lanka concerning the Promotion and Reciprocal Protection of Investments (adopted 7 June 2000, entered into force 16 January 2004), Art. 1; see Deutsche Bank v. Sri Lanka, para. 284.

19 E.g. Acuerdo entre la República Argentina y la República Italiana sobre Promoción y Protección de las Inversiones (adopted 22 May 1990, entered into force 14 October 1993) [Argentina-Italy BIT], Art. 1(1)(c) (the translation to "obligation" was disputed) and 1(1)(f); see Ambiente Ufficio v. Argentina, paras. 488-95, in which the tribunal described the latter provision as a "catchall clause".

20 E.g. Treaty between the United States of America and the Republic of Zaire Concerning the Reciprocal Encouragement and Protection of Investment (adopted 3 August 1984, entered into force 28 July 1989) S Treaty Doc. No. 99-17 (1986), Art. 1(c) (defining investment as "every kind of investment"); see Mitchell v. Democratic Republic of the Congo, ICSID Case No. ARB/99/7, Award (9 February 2004), para. 46.

21 Sattorova, n. 4, 277.

22 Comprehensive Economic and Trade Agreement (CETA) between Canada, of the one part, and the European Union and its Member States, of the other part (adopted 30 October 2016, provisionally entered into force 21 September 2017) [2017] OJ L11/23. However, the provisional application of Art. 8.1 is limited to foreign direct investment: see Notice concerning the provisional application of the Comprehensive Economic and Trade Agreement (CETA) between Canada, of the one part, and the European Union and its Member States, of the other part (16 September 2017) [2017] OJ L238/9. 
(g) intellectual property rights;

(h) other moveable property, tangible or intangible, or immovable property and related rights;

(i) claims to money or claims to performance under a contract.

For greater certainty, claims to money does not include:

(a) claims to money that arise solely from commercial contracts for the sale of goods or services by a natural person or enterprise in the territory of a Party to a natural person or enterprise in the territory of the other Party.

(b) the domestic financing of such contracts; or

(c) any order, judgment, or arbitral award related to sub-subparagraph (a) or (b).

Returns that are invested shall be treated as investments. Any alteration of the form in which assets are invested or reinvested does not affect their qualification as investment;

investor means a Party, a natural person or an enterprise of a Party, other than a branch or a representative office, that seeks to make, is making or has made an investment in the territory of the other Party;

12. Article 8.1 CETA uses an asset-backed definition of investment ("every kind of asset"), coupled with illustrative examples of investments. However, it also contains some exclusions such as claims to money related to the delivery of goods or services, and associated judgments and awards. The definition also relies on characteristics of investments that Schreuer and the Salini tribunal identified (see below para. 47). In a similar vein, Article 14.1 United States-Mexico-Canada Agreement (USMCA) refers to "every asset ... that has the characteristics of an investment, including such characteristics as the commitment of capital or other resources, the expectation of gain or profit, or the assumption of risk". ${ }^{23}$ That article further adds illustrative examples and exclusions such as "commercial contracts for the sale of goods or services":

investment means every asset that an investor owns or controls, directly or indirectly, that has the characteristics of an investment, including such characteristics as the commitment of capital or other resources, the expectation of gain or profit, or the assumption of risk. An investment may include:

(a) an enterprise;

(b) shares, stock and other forms of equity participation in an enterprise;

(c) bonds, debentures, other debt instruments, and loans;

[fn. 1: Some forms of debt, such as bonds, debentures, and long-term notes or loans, are more likely to have the characteristics of an investment, while other forms of debt, such as claims to payment that are immediately due, are less likely to have these characteristics.]

(d) futures, options, and other derivatives;

(e) turnkey, construction, management, production, concession, revenue-sharing, and other similar contracts;

(f) intellectual property rights;

23 Agreement between the United States of America, the United Mexican States, and Canada (adopted 30 November 2018, amended 10 December 2019, entered into force 1 July 2020). 
(g) licenses, authorizations, permits, and similar rights conferred pursuant to a Party's law; and

[fn. 2: Whether a particular type of license, authorization, permit, or similar instrument (including a concession to the extent that it has the nature of such an instrument) has the characteristics of an investment depends on such factors as the nature and extent of the rights that the holder has under a Party's law. For greater certainty, among such instruments that do not have the characteristics of an investment are those that do not create any rights protected under the Party's law. For greater certainty, the foregoing is without prejudice to whether any asset associated with such instruments has the characteristics of an investment.]

(h) other tangible or intangible, movable or immovable property, and related property rights, such as liens, mortgages, pledges, and leases,

but investment does not mean:

(i) an order or judgment entered in a judicial or administrative action;

(j) claims to money that arise solely from:

(i) commercial contracts for the sale of goods or services by a natural person or enterprise in the territory of a Party to an enterprise in the territory of another Party, or

(ii) the extension of credit in connection with a commercial contract referred to in subparagraph (j)(i);

13. A similar approach can be found in definition of investment under the EUVietnam Investment Protection Agreement, ${ }^{24}$ which excludes "claims to money that arise solely from commercial contracts for the sale of goods or services ... or any related order, judgement, or arbitral award". ${ }^{25}$

14. By contrast, the India Model BIT excludes a wider range of transactions, including portfolio investment. ${ }^{26}$ For example, Article 2.4.1(iv) of the Brazil-India

24 EU-Vietnam Investment Protection Agreement (adopted 30 June 2019, not in force), Art. 1(h): “"investment' means every kind of asset which is owned or controlled, directly or indirectly, by an investor of a Party in the territory of the other Party, which has the characteristics of an investment, including such characteristics as the commitment of capital or other resources, the expectation of gain or profit, the assumption of risk and a certain duration; forms that an investment may take include: (i) tangible or intangible, movable or immovable property, as well as any other property rights, such as leases, mortgages, liens and pledges; (ii) an enterprise as well as shares, stocks and other forms of equity participation in an enterprise, including rights derived therefrom; (iii) bonds, debentures, and loans and other debt instruments, including rights derived therefrom; (iv) turnkey, construction, management, production, concession, revenue-sharing and other similar contracts; (v) claims to money or to other assets or any contractual performance having an economic value; and (vi) intellectual property rights and goodwill; returns that are invested shall be treated as investments provided that they have the characteristics of an investment and any alteration of the form in which assets are invested or reinvested shall not affect their qualification as investments as long as they maintain the characteristics of an investment" (footnotes omitted).

25 EU-Vietnam Investment Protection Agreement, Art. 1(h)(v) fn. 1.

26 Model Text for the Indian Bilateral Investment Agreement (approved 28 December 2015), Art. 1.4(i). In 2015, India circulated its draft Model BIT and terminated most of its existing BITs. See Department of Economic Affairs, "Bilateral Investment Treaties (BITs)/Agreements" https://dea.gov.in/bipa accessed 17 November 2020. 
BIT states that "investment" does not include "portfolio investments of the enterprise or in another enterprise". ${ }^{27}$ The India-Taiwan BIT also contains a similar definition and categorises portfolio investments as an ownership interest of less than 10 per cent. ${ }^{28}$ Similar to the above treaties, the India Model BIT and India's treaties concluded thereafter rely on the elements of investments that Schreuer and the Salini tribunal identified or a variant thereof. Provided the purchases of shares amount to foreign direct investment, rather than portfolio investment, such transactions qualify as investments under these investment treaties. $^{29}$

15. At bottom, there are two different conceptions of "investment" that tribunals and the literature use. The first conception considers that States have the freedom to customise what counts as an investment in their BITs, without limitation. There is no numerus clausus principle in international investment law - the definition of investment is akin to contract. ${ }^{30}$ The second conception considers that the notion of "investment" in Article 25 ICSID Convention is akin to property. A numerus clausus applies, and hence only interests that conform to a limited number of standard forms are protected. ${ }^{31}$

\section{B. Evolving the meaning of investment through interpretation}

16. As the next subsection below shows, the drafters of the ICSID Convention left the notion of "investment" ambiguous. And even if the meaning of "investment" in Article 25 ICSID Convention was narrower than the definition of investment in modern investment treaties, it does not necessarily follow that this notion of investment remains the same today as in 1965. The "objective" meaning of investment could assume a broader, more modern meaning through interpretation. The meaning of treaty terms such as "investment" is not necessarily static but could evolve over time.

17. While there are no known examples of investment tribunals expressly applying evolutionary interpretation in the specific context of the definition of investment, there is no doubt that the meaning of terms such as "investment" can

\footnotetext{
27 Investment Cooperation and Facilitation Treaty between the Federative Republic of Brazil and the Republic of India (adopted on 25 January 2020, not in force), Art. 2.4.1(iv). This treaty does not include investor-State dispute resolution.

28 Bilateral Investment Agreement between the India Taipei Association in Taipei and the Taipei Economic and Cultural Center in India (adopted 18 December 2018, entered into force 14 February 2019), Art. 1.3(i): "portfolio investments of the enterprise or in another enterprise; For greater certainty, portfolio investments means investment through capital instruments where such investment is less than 10 percent of the post issue paid-up capital on a fully diluted basis of a listed enterprise or less than 10 percent of the paid-up value of each series of capital instruments of a listed enterprise."

29 E.g. Enkev Beheer BV v. Republic of Poland, PCA Case No. 2013-01, First Partial Award (29 April 2014) [Enkev Beheer v. Poland] (the claimant acquired 79\% of shares in a Polish company).

30 Cf. J. Arato, "The Private Law Critique of International Investment Law" (2019) 113 American Journal of International Law 1, 2 ("ISDS tribunals have been left to determine the scope of international property, contract, intellectual property, and corporate law that investment treaties impose").

31 See the seminal analysis on domestic law in T. W. Merrill and H. E. Smith, "Optimal Standardization in the Law of Property: The Numerus Clausus Principle" (2000) 110 Yale Law Journal 1.
} 
evolve. ${ }^{32}$ Other international courts and tribunals, including the ICJ, have relied on evolutionary interpretation. ${ }^{33}$ In the Dispute regarding Navigational and Related Rights, the ICJ considered whether the meaning of terms in an 1858 bilateral treaty between Costa Rica and Nicaragua concerning the San Juan River had evolved over the last 150 years. ${ }^{34}$ Considering some subsequent practice of the two disputing States, the ICJ opted for a dynamic interpretation of another economic term, namely "libre navegación con objetos de comercio", albeit of a right rather than a jurisdictional title. The ICJ explained:

[the Court's practice of interpreting clauses in line with their meaning at the time of conclusion] does not however signify that, where a term's meaning is no longer the same as it was at the date of conclusion, no account should ever be taken of its meaning at the time when the treaty is to be interpreted for purposes of applying it. ${ }^{35}$

18. Similarly, the term "investment" in Article 25 ICSID Convention could be found to have an evolutionary character. With respect to treaties concluded for a long period of time, such as the ICSID Convention, "the parties' intent upon conclusion of the treaty was, or may be presumed to have been, to give the terms used - or some of them - a meaning or content capable of evolving, not one fixed once and for all, so as to make allowance for, among other things, developments in international law". ${ }^{36}$

19. Even though no investment tribunal thus far has expressly couched its analysis of "investment" in these terms, in some awards - such as Abaclat $^{37}$ tribunals arguably adopted the view that "investment" has an evolutionary meaning. ${ }^{38}$ Arbitrator Abi-Saab dissented vigorously on this point, referring to the

32 But see RosInvestCo UK Ltd v. The Russian Federation, SCC Case No. V079/2005, Award on Jurisdiction (1 October 2007), paras. 37-44, 100 (rejecting the investor's argument that the dispute resolution clause in the BIT was subject to a dynamic, evolutionary interpretation and that the BIT was a living instrument). The tribunal seemingly distinguished between bilateral treaties such as investment treaties, and "long term multilateral convention(s) on human rights", where there may be a role for evolutionary interpretation.

33 On evolutionary interpretation generally, E. Bjorge, The Evolutionary Interpretation of Treaties (Oxford University Press, 2014); C. Djeffal, Static and Evolutive Treaty Interpretation: A Functional Reconstruction (Cambridge University Press, 2016); P. Tzeng, "The Principles of Contemporaneous and Evolutionary Interpretation", in J. Klingler, Y. Parkhomenko and C. Salonidis (eds.), Between the Lines of the Vienna Convention? Canons and Other Principles of Interpretation in Public International Law (Wolters Kluwer, 2019), 387-422; G. Abi-Saab, K. Keith, G. Marceau and C. Marquet (eds.), Evolutionary Interpretation and International Law (Hart, 2019).

34 Dispute regarding Navigational and Related Rights (Costa Rica v. Nicaragua) Judgment, ICJ Reports 2009, 213; M. Waibel, "International Investment Law and Treaty Interpretation", in R. Hofmann and C. J. Tams (eds.), International Investment Law and General International Law: From Clinical Isolation to Systemic Integration? (Nomos, 2011), 29-52 [Waibel, "Treaty Interpretation"], 35. Cf. also Award in the Arbitration regarding the Iron Rhine ("Ijzeren Rijn") Railway between the Kingdom of Belgium and the Kingdom of the Netherlands, decision of 24 May 2005, XXVII UNRIAA 35.

35 Costa Rica v. Nicaragua, para. $64 . \quad 36$ Ibid.

37 The Abaclat tribunal contrasted the ICSID Convention to the BIT practice of both home and host State to "identify two different aspects" of the concept of investment differing in the BIT and the ICSID Convention. Abaclat v. Argentina, paras. 343-8.

38 J. Arato and A. Kulick, "Final Report on International Investment Tribunals", ILA Study Group on the Content and Evolution of the Rules of Interpretation, 29 November-13 December 2020, 6-7; AbiSaab, Keith, Marceau and Marquet, n. 33, Chapters 23-6. 
"tenuous and untenable interpretations, particularly of jurisdictional titles, overstretching the text beyond the breaking point, in order to extend jurisdiction to where it does not exist". ${ }^{39}$ The Salini tribunal's finding on the "contribution to economic development of the host State" could also be seen as evolutionary interpretation because the tribunal did not pay regard to what this phrase meant in $1965 .^{40}$ The annulment committee in Mitchell v. DRC acknowledged that some cases "broadened" the meaning of investment compared to the 1965 meaning of investment, but concluded that this did not change the meaning in the instant case. $^{41}$

20. The tribunal in HICEE v. Slovakia, a non-ICSID arbitration, adopted an anticipatory, rather than evolutionary, approach to investment treaty interpretation. The dispute concerned shares in two Slovak health insurance companies. The tribunal was open to interpret the investment treaty based not on the conditions at the time of its negotiation but rather the economic transition that the parties anticipated for the future:

The Tribunal only feels it necessary to observe that BITs are, by definition, concluded for the future not just for the present, and that there was nothing to prevent either side - i.e. the Dutch side quite as much as the Czechoslovak side - wanting to provide in advance for a more liberal economic regime that was on its way. ${ }^{42}$

21. As a matter of treaty interpretation, the definition of "investment" in an investment treaty can affect the interpretation of "investment" in Article 25 ICSID Convention in three ways. A first possibility is that the investment treaty qualifies as a subsequent agreement or subsequent practice under Article 31(3)(a) or (b) VCLT between two States both of which are parties to the ICSID Convention. ${ }^{43}$ Investment treaties could impact the meaning of "investment" in Article 25 ICSID Convention through subsequent agreement (subparagraph (a) of Article 31(3) VCLT) or subsequent practice (subparagraph (b) of Article 31(3) VCLT). However, the insurmountable hurdle for both is that subsequent agreements and practice need to be common to all parties to the treaty, and that the rules need to be applicable in the relationship between all the parties. ${ }^{44}$ As Pahis notes, "BITs are

39 Abaclat and Others (Case Formerly Known as Giovanna a Beccara and Others) v. Argentine Republic, ICSID Case No. ARB/07/5, Dissenting Opinion, Georges Abi-Saab (28 October 2011) [Abaclat v. Argentina Dissent], para. 273.

${ }_{40}$ M. M. Mbengue and A. Florou, "Evolutionary Interpretation in Investment Arbitration: About a Judicial Taboo", in Abi-Saab, Keith, Marceau and Marquet, n. 33, 255-6.

41 Mitchell v. DRC Annulment, para. 30. See also Mbengue and Florou, n. 40, 256.

42 HICEE BV v. Slovak Republic (PCA Case No. 2009-11), Partial Award (23 May 2011) [HICEE v. Slovakia], para. 120.

43 The VCLT does not apply to the ICSID Convention 1965, because the VCLT is only applicable to treaties which are concluded after the entry into force of the VCLT: see Vienna Convention on the Law of Treaties (adopted 23 May 1969, entered into force 27 January 1980) 1155 UNTS 331 [VCLT], Art. 4. But Article 31 VCLT is seen as reflective of customary international law: see O. Dörr, "Article 31", in O. Dörr and K. Schmalenbach (eds.), Vienna Convention on the Law of Treaties: A Commentary (Springer, 2018), paras. 6-7.

44 Whaling in the Antarctic (Australia v. Japan: New Zealand intervening) Judgment, ICJ Reports 2014, 226, para. 83 (agreement and practice need to be universal among all parties to the treaty). 
neither of these. An agreement between two of the State parties to the ICSID Convention cannot "establish the agreement of the parties regarding [the] interpretation' by all the other [ICSID State parties]." 45

22. A second possibility is that the investment treaty is "relevant rules applicable in the relations between the parties" under Article 31(3)(c) VCLT. Accordingly, the definition of investment in the investment treaty could be relevant for interpreting the notion of "investment" in Article 25 ICSID Convention in so far as the two parties inter se are concerned. In this respect, Article 31(3)(c) is concerned with "the extent to which other treaty relations between the parties may have an interpretative role". ${ }^{46}$ Gardiner finds some support in the preparatory works of the VCLT that treaties, including bilateral ones, are within the scope of the "rules" that Article 31(3)(c) envisages, but cautions that practice is only "gradually emerging". ${ }^{47}$ Unlike subsequent agreement or practice above, it is not established that congruence of membership between the treaty that one seeks to interpret and the second treaty that is used to interpret the first treaty is necessary.

23. With respect to the "parties" that need to share the interpretation, Pauwelyn argues in the context of the WTO agreements that all the parties to the treaty under interpretation must have assented, at least implicitly, to the second treaty used to interpret the first. ${ }^{48}$ Gardiner, however, notes that practice and academic writing do not lead to "any firm outcome". ${ }^{49}$ He takes the view that the "omission of "all' combined with the phrase 'applicable in the relations between the parties'... makes more sense if referring to relations between the parties having an immediate interest in the issue of interpretation, rather than all states parties to the treaty that is being interpreted". ${ }^{0}$ The implication is that the definition of investment in the investment treaty may shed light on the meaning of investment in Article 25 ICSID Convention.

24. A third and much more far-fetched possibility is that the investment treaty's definition represents an inter se agreement under Article 41 VCLT between two parties to the ICSID Convention in respect of the definition of investment in Article 25 ICSID Convention. ${ }^{51}$ This argument is likely to fail because the

45 S. Pahis, "Investment Misconceived: The Investment-Commerce Distinction in International Investment Law" (2020) 45 Yale Journal of International Law 69, fn. 58; Waibel, "Opening Pandora's Box", n. 2, 718 and 730.

46 R. Gardiner, "The Vienna Convention Rules on Treaty Interpretation", in D. B. Hollis (ed.) The Oxford Guide to Treaties (Oxford University Press, 2nd edn, 2020), 469.

47 Ibid., 471; R. Gardiner, Treaty Interpretation (Oxford University Press, 2nd edn, 2015), 301, quoting ILC member Yasseen in [1966] Yearbook of the ILC, vol. I, part II, 197, para. 52; Pahis, "Investment Misconceived", n. 45, 69, fn. 58. E.g. Pope \& Talbot Inc. v. Government of Canada, UNCITRAL, Award in Respect of Damages (31 May 2002), para. 46 ("international law is a broader concept than customary international law").

48 J. Pauwelyn, Conflict of Norms in Public International Law: How WTO Law Relates to Other Rules of International Law (Cambridge University Press, 2003), 257-61.

49 Gardiner, Treaty Interpretation, n. 47, 311. Cf. also C. McLachlan, "The Principle of Systemic Integration and Article 31(3)(c) of the Vienna Convention" (2005) 54 International and Comparative Law Quarterly 279.

50 Gardiner, Treaty Interpretation, n. 47, 304.

51 The VCLT does not apply to the ICSID Convention (n. 43). Whether the whole of Article 41 VCLT is reflective of customary international law is controversial. Von der Decken argues that "[i]t is more 
requirements of Article 41 VCLT are not met. Specifically, Article 41(1)(b)(i) requires that the purported modification "does not affect the enjoyment by the other parties [ICSID member States] of their rights under the treaty or the performance of their obligations". But if the class of investments covered by Article 25 ICSID Convention were to be amended by inter se agreement, the enforcement obligations of all ICSID member States would increase. ${ }^{52}$ And even if the requirements were met, it would be difficult to show that the investment treaty amounts to a modification. In practice, parties to investment treaties do not notify all the parties to the ICSID Convention that their investment treaty modifies the ICSID Convention, pursuant to the procedural obligation to notify in Article 41(2) VCLT.

\section{The inconclusive travaux préparatoires on the definition of investment}

25. During the period from the 1960s to the 1980s, when investment contracts were the primary instrument of consent for ICSID arbitration, ICSID subject matter jurisdiction was much more straightforward compared with the era of arbitration without privity, from the 1990s until the present, in which investment treaties are the main instrument of consent. ${ }^{53}$ By agreeing to include an ICSID arbitration clause in the investment contract, the host State expressed its view that the specific investment at issue in this particular investment contract qualifies as an investment. By contrast, investment treaties (as well as domestic investment codes) cover a wide range of transactions that are not specified in advance.

26. When the ICSID Convention was drafted, no one could foresee the explosion in investment treaty making that followed, particularly in the 1990s. ${ }^{54}$ States had signed only 26 treaties when the Consultative Meeting of Legal Experts that was tasked with drafting the ICSID Convention first met in Addis Ababa in December 1963, and had signed only 39 investment treaties when they signed the ICSID Convention on 18 March $1965 .{ }^{55}$ At the time, only two traditionally capital-exporting States (Germany and Switzerland) had begun their investment

\footnotetext{
likely that the principle embodied in Art. 41 reflects customary law"; Rigaux and others state that "constant practice resolutely points in favour of" customary international law. K. von der Decken, "Article 41", in O. Dörr and K. Schmalenbach (eds.), Vienna Convention on the Law of Treaties: A Commentary (Springer, 2018), para. 8; A. Rigaux, D. Simon, J. Spanoudis and E. Weemaels, "Article 41: Convention of 1969", in O. Corten and P. Klein (eds.), The Vienna Conventions on the Law of Treaties: A Commentary: Volume II (Oxford University Press, 2011), para. 17.

52 R. Castro de Figueiredo, "The Investment Requirement of the ICSID Convention and the Role of Investment Treaties" (2015) 26 American Review of International Arbitration 453, 480-1; Pahis, "Investment Misconceived", n. 45, 79-81 contends that the requirements of Article 41 are not fulfilled ("Expanding ICSID jurisdiction beyond Article 25 'investment' would impose additional obligations upon other Contracting States, including a potential increase in financial and enforcement obligations resulting from a larger ICSID caseload").

53 J. Paulsson, "Arbitration Without Privity" (1995) 10 ICSID Review - Foreign Investment Law Journal 232.

54 J. Bonnitcha, L. Poulsen and M. Waibel, The Political Economy of the Investment Treaty Regime (Oxford University Press, 2017), 20, Figure 1.5.

55 Based on data from https://icsid.worldbank.org/resources/databases/bilateral-investment-treaties and https://investmentpolicy.unctad.org/international-investment-agreements (accessed 12 October 2020).
} 
treaty programmes: only two of the 26 treaties signed by 20 December 1963, and only five of the 39 treaties signed by 18 March 1965, had neither Germany nor Switzerland as a party. ${ }^{56}$

27. The proper interpretation of the travaux préparatoires to Article 25 ICSID Convention on the definition of investment has given rise to sustained controversy. While negotiating the ICSID Convention, States made multiple attempts to define investment but failed due to divergent views on the scope of investment. ${ }^{57}$ It was not surprising that developed and developing countries split on this point. ${ }^{58}$ The lack of a definition of "investment" in Article 25 ICSID Convention was not due to happenstance. Until the end of the negotiations of the ICSID Convention, States had different understandings of "investment". 59

28. Notwithstanding, the Report of the Executive Directors 1965 expressly noted that "[n]o attempt was made to define the term "investment". 60 The same sentence explains that delegates chose not to define "investment" given "the essential requirements of consent by the parties". ${ }^{61}$ However, the 1965 Report does not mention the wider context of divergent views among the delegates on the notion of "investment" during the negotiations. ${ }^{62}$

29. On 9 August 1963, the Executive Directors of the World Bank discussed a "First Preliminary Draft of a Convention on the Settlement of Investment Disputes between States and Nationals of Other States". This first draft did not contain a reference to "investment", or more generally, to subject matter jurisdiction. The second draft, the "Preliminary Draft Convention" of 15 October 1963, contained a reference to "investment" as a limitation. State experts discussed this draft between December 1963 and May 1964 in four Consultative Meetings of Legal Experts. Based on these meetings, the World Bank prepared a third draft, the "Draft

56 The others were the Netherlands, France, Italy, Belgium-Luxembourg and the outlier of the IraqKuwait BIT 1964. On the timeline of the drafting history of the ICSID Convention, see International Centre for Settlement of Investment Disputes, History of the ICSID Convention: Documents Concerning the Origin and the Formulation of the Convention on the Settlement of Investment Disputes between States and Nationals of Other States (1968), Vol. II-1 [ICSID History Vol. II-1]; ICSID History Vol. II-2, n. 10, 2; Mortenson, n. 2, 280-96.

57 E.g. "Article 25" in C. Schreuer, The ICSID Convention: A Commentary (Cambridge University Press, 1st edn, 2001) ["Article 25" 1st edn], para. 5. ("In the course of the Convention's drafting, there were extensive discussions as to whether the objective criteria, notably 'investment', 'legal dispute' and the investor's nationality, required precise definition.")

58 A. Parra, The History of ICSID (Oxford University Press, 2nd edn, 2017), 79; Malaysian Historical Salvors Sdn, Bhd v. Government of Malaysia, Dissenting Opinion of Judge Mohamed Shahabuddeen (16 April 2009) [Malaysian Historical Salvors v. Malaysia Annulment Dissent], para. 62 (the outer limits approached as a "titanic struggle between ideas, and correspondingly between capital exporting countries and capital importing ones"); Sattorova, n. 4, 271 ("systemic tension between competing visions of international investment law"); Mortenson, n. 2, 260.

59 Schreuer, “Article 25" 1st edn, n. 57, paras. 81-8, esp. 86; Hwang and Fong Lee Cheng, n. 9, 108 (noting the subsequent absence of a consensus on the definition of investment).

60 Report of the Executive Directors of the International Bank for Reconstruction and Development on the Convention on the Settlement of Investment Disputes between States and Nationals of Other States, 18 March 1965, para. 27 ("Report of the Executive Directors 1965").

61 Ibid.

62 Mortenson, n. 2, 292 (referring to the "startling inaccuracy of the suggestion that there was no attempt to define "investment"”). 
Convention" dated 11 September 1964. The third draft provided the basis for discussions with States in the Legal Committee. This draft also contained a reference to "investment" as a limitation. It defined this notion as follows:

any contribution of money or other asset of economic value for an indefinite period or, if the period be defined, for not less than five years. ${ }^{63}$

30. These discussions led to the adopted text of the ICSID Convention, signed on 18 March $1965 .{ }^{64}$ The final version of the text contains the term "investment" but does not offer a definition. All proposals on the meaning of "investment" during the drafting history did not make it into the final text. An unapproved record of the Meeting of the Committee of the Whole on 16 February 1965 reads:

Mr. Broches [World Bank General Counsel and Chairman of the Legal Committee] said that the staff had prepared a definition of "investment" and had also brought to the attention of the Legal Committee a number of examples of definitions of that term taken from legislation and bilateral agreements. None of these had proved acceptable. The large majority had, moreover, agreed that while it might be difficult to define "investment" an investment was in fact readily recognizable. The Report would say that the Executive Directors did not think it necessary or desirable to attempt to define the term "investment" given the essential requirement of consent of the parties and the fact that Contracting States could make known in advance within what limits they would consider making use of the facilities of the Centre. Thus each Contracting State could, in effect, write its own definition. ${ }^{65}$

31. Earlier, however, on 25 November 1963, Broches stated the notion of "investment" was not equivalent to State consent to the Centre's jurisdiction:

[I]n the context of this Convention, the term "jurisdiction" does not mean compulsory jurisdiction, but rather the outer limits within which use can be made of the facilities provided for by the Center. In other words, one is here only concerned with a limitation of the scope of the Convention. Such a limitation is necessary in spite of the fact that the submission of disputes was subject to the consent of the parties concerned, since this Convention was intended to deal, first with a specific field, namely investments, and second with a particular category of disputes, namely disputes between Contracting States and nationals of other Contracting States. This explained why some of the definitions might lack the precision which would be quite essential if one dealt with a case of compulsory jurisdiction. ${ }^{66}$

32. These two statements by Broches provide no clear answer on the notion of investment. The unapproved minutes capture the inconclusiveness of the

63 ICSID History Vol. II-1, n. 56, 623. See also Mortenson, n. 2, 281-6.

64 Convention on the Settlement of Investment Disputes between States and Nationals of Other States (adopted 18 March 1965, entered into force 14 October 1966) 575 UNTS 159.

65 ICSID History Vol. II-2, n. 10, 972 (emphases added).

66 Ibid., 700 (emphases added). Cf. A. Broches, Selected Essays: World Bank, ICSID, and Other Subjects of Public and Private International Law (M. Nijhoff Publishers, 1995), 208 (Broches also described it as "wise" to "leave a large measure of discretion to the parties", but highlighting that such discretion was "not unlimited and cannot be exercised to the point of being clearly inconsistent with the purposes of the Convention"). 
discussions during the drafting of the ICSID Convention. Like the discussions themselves, this summary of the discussion showed that State delegates diverged on the meaning of investment. On the one hand, this summary states that an investment is "readily recognizable" without furnishing a definition (implying that there is an objective meaning of investment). On the other hand, States could write their own definitions (the subjective meaning of investment).

33. The formulation "did not think it necessary or desirable to attempt to define the term "investment"' in the extract of the minutes above, which also featured in the Draft Report of the Executive Directors, ${ }^{67}$ ended up only a month later in the official Report of the Executive Directors but in the following variation: "[n]o attempt was made to define the term "investment"". ${ }^{68}$ However, the reference to the lack of need and the undesirability of defining "investment" disappeared. To some delegates, the reason for not defining investment was strategic - it was unnecessary and undesirable. However, for others it was the divergent views among States that led an inability to define the term, even though a definition was desirable. ${ }^{69}$ In sum, the travaux to the ICSID Convention shed limited light on the notion of investment, beyond showing that there was much disagreement over what this notion referred to.

34. This controversy over whether the meaning of "investment" in Article 25 ICSID Convention is subjective or objective is important in practice: the more constraining the elements for determining objectively whether a transaction amounts to an investment (to which Section III now turns), the more limited the discretion enjoyed by ICSID tribunals on this matter. Conversely, the more degrees of freedom tribunals enjoy as regards these elements, the less relevant the controversy over the subjective or objective meaning of investment. If tribunals apply the elements very pragmatically, the objective or subjective view changes little to nothing with respect to the jurisdiction of ICSID tribunals.

\section{THE OBJECTIVE ELEMENTS OF INVESTMENTS}

35. This Section examines whether there are any objective elements for investments under Article 25 ICSID Convention and, if so, what these elements are according to investment tribunals and the literature. We begin with the travaux préparatoires of the ICSID Convention, before examining three different approaches to the objective meaning of investment: (i) Salini's positive criteria for investment, or variants thereof; (ii) an almost unlimited meaning of investment,

67 ICSID History Vol. II-2, n. 10, 957 (Doc. 128, para. 26) and 1027.

68 ICSID History Vol. II-2, n. 10, 1078. See also Mortenson, n. 2, 292-3.

69 ICSID History Vol. II-2, n. 10, 1027: Mr Mejia-Palacio, Executive Director of the World Bank for Brazil, the Philippines, Colombia, Ecuador and the Dominican Republic, "said that it would not be correct to say ... 'The Executive Directors did not think it necessary or desirable to attempt to define the term "investment". In his opinion, it was difficult to define that term but he could not support the idea that a definition was unnecessary or undesirable." In response to this complaint, Mr. Broches proposed the words that would appear in the Final Report. 
excluding only facially absurd instances not connected to a plausible economic activity; (iii) a negative definition of investments that distinguishes investment, on the one hand, over which ICSID tribunals have jurisdiction, from commercial transactions, on the other hand, over which ICSID tribunals lack jurisdiction. These three approaches can overlap in practice. The Section concludes by looking at the relevance of the objective elements of investments in arbitrations governed by the ICSID Additional Facility Rules, the UNCITRAL Rules and SCC Rules.

\section{A. Objective elements of investments in the negotiations of the ICSID Convention}

36. Countries disagreed on the need for, and desirability of, a definition of objective elements of an investment during the negotiation of the ICSID Convention, similar to the fault lines that emerged during the negotiations on whether the meaning of investment was objective or subjective (see Section II above). As a rule, developed countries tended to favour a subjective meaning and developing countries an objective meaning of investments. ${ }^{70}$ The travaux préparatoires of the ICSID Convention show that there was no agreement on what the objective elements for identifying investment could or should be leaving the task of coming up with elements to investment tribunals from the 1990s onwards, and to scholars (the first award where the host State objected to the transaction qualifying as an investment under Article 25 ICSID Convention, and where an ICSID tribunal thus analysed this question in some detail, was Fedax v. Venezuela in 1997). ${ }^{71}$ More fundamentally, during the drafting of the ICSID Convention, countries also disagreed on whether such elements were desirable in the first place.

37. Countries have also adopted divergent approaches on the elements for defining investments in their bilateral investment treaty programmes. For example, the UK emphasised the desirability of a definition that was as wide as possible in its bilateral investment treaty negotiations from the 1980s onwards. It also insisted to its prospective treaty partners that the non-exhaustive character of the definition of investment be preserved. ${ }^{72}$ There are no indications that the UK contemplated any implicit objective definition of investment that would require transactions between host States and foreign investors to display certain inherent features.

38. In the negotiations on the ICSID Convention, Australia suggested the following definition: "Investment means every mode or application of money

70 Cf. T. St John, The Rise of Investor-State Arbitration: Politics, Law, and Unintended Consequences (Oxford University Press, 2018), 168-9 (noting the absence of monolithic blocs of developed and developing countries, with several developed countries favouring limits).

71 Fedax v. Venezuela, paras. 18ff. It was also the first award that referred to Schreuer's investment characteristics: see ibid., para. 43 (referring to C. Schreuer, "Commentary on the ICSID Convention: Article 25" (1996) 11 ICSID Review - Foreign Investment Law Journal 355, 372). See also Salini v. Morocco, para. 52. Cf. Schill, “Article 25”, n. 6, para. 235.

72 J. Hepburn, M. Paparinskis, L. Poulsen and M. Waibel, "Investment Law before Arbitration" (2020)

23 Journal of International Economic Law 929, 939. 
which is intended to return interest for profit." ${ }^{, 73}$ Germany, which at the time of discussions had already signed around a dozen bilateral investment treaties, which accounted for approximately half of all investment treaties at the time, suggested that the delegates look to existing treaties which "refer to the term "property, rights and interests". ${ }^{74} \mathrm{Mr}$. Broches rejected this suggestion, as existing "definitions had convinced the draftsmen that they could hardly use them as models since they were always directed towards particular facts or situations". ${ }^{75}$

39. Austria favoured "as general an application as possible" $" 76$ but also acknowledged the difficulty of having a precise definition of the term. ${ }^{77}$ It underscored the desirability "for the Convention to indicate the meaning of this term in order to define which disputes could be brought before the Centre. A descriptive list might be suitable ... public loans or bonds should not be included - but on the other hand, the Convention should cover guarantees given by States to contracts of investment." ${ }^{, 78}$ The Austrian delegate explained further:

the definition "legal disputes arising out of or in connection with any investment" is rather vague. It will, of course, be difficult to define precisely the disputes which would fall within the jurisdiction of the Center. Pursuant to Article 26, paragraph 2, the jurisdiction of the Center depends on the consent of both parties to the dispute, and in particular also the consent of the defendant State (same as in the first draft). The new draft, however, no longer provides explicitly the possibility of general statements of submission, as contained in Article 2, paragraph 2 of the first draft. It is doubtful whether the new formulation is an improvement since it should be the goal of the Convention to allow as general an application as possible. ${ }^{79}$

40. The five Nordic countries opposed a definition, referring to the futility of attempting a definition. They forecast that few jurisdictional difficulties would arise, and those that did arise could safely be delegated by the parties to ICSID tribunals. Their joint statement shows what also appears to be the final result of the ICSID Convention: States, even if they rejected a definition, still had their own views of what the term "investment" means:

[B]ecause of the condition of consent, there would be no need for complicated definitions. With respect to the term "investment", the examples circulated by the Secretariat proved how futile it would be to attempt a definition. Since the parties would be free to submit their disputes to the Centre ... difficulties would [not] arise in practice and that, should difficulties arise, they should be dealt with by the tribunal. Therefore, [it is preferable that] no definition of the term "investment" be provided for in the Convention. In any case, ... the definition included in the present draft suffered from various defects, being both too wide (for instance, seems to include portfolio investments) and too narrow (provides for time limits). ${ }^{80}$

\footnotetext{
73 ICSID History Vol. II-2, n. 10, $704 . \quad 74$ Ibid.

75 Ibid. 76 Ibid., 670.

77 Ibid., $709 . \quad 78$ Ibid.

79 Ibid., 670. $\quad{ }^{80}$ Ibid., 706-7.
} 
41. Nevertheless, most developing countries underscored the desirability of a definition. For example, China considered the attempt of the World Bank staff to define investment in the Draft Convention of 11 September 1964 "too imprecise and that the condition of consent was too weak to exclude certain undesirable matters from submission to the Center". ${ }^{81}$ India favoured including "only 'substantial' investments" relating "to the total value of the investment rather than to the duration of it". 82

42. Towards the end of the discussions, the two main proposals - the British and the Spanish proposals - lacked a definition of investment. ${ }^{83}$ Rather than including a narrowly defined list of investments, ${ }^{84}$ the Spanish proposal itself stated that it did not define investment but rather sought a limitation of ICSID's jurisdiction through other means:

The delegation submitting this proposal understands that to define the concept of investment, in view of the multiple legal economic and financial aspects that it may contain, is a well-nigh impossible task, and it thinks it would be more logical to delimit the action of the Centre, not on a definition of investment, but rather on a definition of competence. ${ }^{85}$

43. According to the British proposal, ICSID jurisdiction was limited to investment disputes. Crucially, "investment" was left undefined. To the British proponents, a definition was unnecessary because of an innovative feature that allows each State - at any time - to opt into or out of those disputes which in its view are unsuitable for adjudication by ICSID: ${ }^{86}$

(1) The jurisdiction of the Centre shall extend to investment disputes between a Contracting State and a national of another Contracting State, which the parties to the dispute consent in writing to submit to the Centre. When the parties have given their consent, no party may withdraw its consent unilaterally. (2) Any Contracting State may at the time of ratification or accession or at any time thereafter notify to the Centre the class or classes of investment disputes in respect of which it would in

81 Ibid., 700

82 Ibid., 706. India's decision not to join the ICSID Convention appears to have been based on concerns other than the definition of investment: P. Ranjan, India and Bilateral Investment Treaties: Refusal, Acceptance, Backlash (Oxford University Press, 2019), 87-92.

83 ICSID History Vol. II-2, n. 10, 842 (the Spanish proposal): "(1) The jurisdiction of the Centre is extended to the solution of all legal differences between a Contracting State and a national of another Contracting State when it refers directly to an investment and is intended to achieve: (a) fulfilment of commitments arising out of a contract entered into between the State and the national of another State; (b) fulfilment of guarantee commitments that may have been given by a State to specific investments; (c) decision, even in the cases of investments made without the intervention of the State, but in observance of the provisions of law, on the reestablishment of the legal status and, should this be impossible or should the State not agree to such reestablishment, on the indemnity that is in order as a result of measures adopted by the said State which violate the rights of the national of the other State, provided that such measures do not arise out of the application of laws of a general nature and should they arise from laws of such a nature, when they annul or reduce benefits of the investor that have been expressly recognized by the said State."

${ }_{84}$ But see Mortenson, n. 2, $291 . \quad{ }_{85}$ ICSID History Vol. II-2, n. $10,841$.

86 Report of the Executive Directors 1965, n. 60, para. 31. Italy and the Netherlands proposed this optout mechanism: ICSID History Vol. II-2, n. 10, 823, 829, 840; Parra, n. 58, 80-1. 
principle consider submitting or not submitting to the jurisdiction of the Centre. Such notification shall not constitute the consent required by paragraph (1). ${ }^{87}$

44. The final version of Article 25 ICSID Convention contains a modified version of the British proposal. According to Mortenson, this compromise was "permissive", charging individual States "with doing the tailoring themselves". ${ }^{88}$ Based on additional archival research, however, St John shows that this was not the "final word" and that Broches' (influential) view and the views of the Drafting Committee on this point did not necessarily coincide. ${ }^{89}$ British officials asked Broches for clarification on the definition of investment after the Convention's entry into force, and in particular noted the lack of certainty on whether the ICSID Convention covered portfolio investors. ${ }^{90}$

45. Considering the "well-nigh impossible task" of defining investment, ${ }^{11}$ delegates were unable to reach consensus - and they agreed to disagree. ${ }^{92}$ They chose to include the term "investment" without providing a definition, without agreeing what was meant by the term, and without specifying by which elements investment tribunals should evaluate whether transactions amount to investments. Article 25 ICSID Convention is a good illustration of how States reduce their disagreement to writing. ${ }^{93}$

46. Against the ambiguity of Article 25 ICSID Convention on the meaning of investment, three approaches have emerged that we examine in turn: (i) Salini's positive criteria for investment; (ii) an almost unlimited meaning of investment; and (iii) a negative definition of investments that distinguishes investments from commercial transactions. The following subsections examine these three approaches.

\section{B. The Salini criteria and their critics}

\section{In July 2001, the tribunal in Salini held:}

The doctrine generally considers that investment infers: contributions, a certain duration of performance of the contract and a participation in the risks ... In reading

87 ICSID History Vol. II-2, n. 10, 821 (emphasis added). Such inclusions or exclusions do not count as reservations: Report of the Executive Directors 1965, n. 60, para. 31. Moreover, the timing of reservations is constrained. States can only enter reservations up to the point when they express their consent to be bound.

88 Mortenson, n. 2, 292.

90 Ibid.

89 St John, n. 70, 169.

91 ICSID History Vol. II-2, n. 10, 841.

92 O. Ben-Shahar, "Filling Gaps in Deliberately Incomplete Contracts" (2005) 2 Wisconsin Law Review 389

93 It is conceivable that Philip Allott's experience as a member of the UK delegation for negotiating the ICSID Convention was one reason why he coined the famous adage of treaties as "disagreements reduced to writing" 35 years later: see P. Allott, "The Concept of International Law" (1999) 10 European Journal of International Law 31, 43. Looking back at his experience, however, Allott remarks that the UK "didn't have much to say about" the Convention, other than successfully "insist[ing] that the centre should be spelt C-E-N-T-R-E", which he quipped was "one of the only things [he] actually achieved in life": "Conversations with Professor Philip James Allott by Lesley Dingle and Daniel Bates: Third Interview: The Return to Cambridge (1973-1980)" Squire Law Library Eminent Scholars Archive (8 March 2011) www.squire.law.cam.ac.uk/sites/www.law.cam.ac.uk/files/images/ www.squire.law.cam.ac.uk/legacy/Media/Eminent\%20Scholars\%20Archive\%20Transcripts/allott\% 20INTERVIEW\%203.pdf (accessed 10 December 2020). 
the Convention's preamble, one may add the contribution to the economic development of the host State of the investment as an additional condition. ${ }^{94}$

48. Almost 20 years after this decision, tribunals have reduced or expanded these elements of investment, ranging from three to six. ${ }^{95}$ Table 2 provides an overview of which elements tribunals have considered to be relevant for the definition of investment in Article 25 ICSID Convention. The awards are in ascending chronological order. Column 2 indicates whether the tribunal affirmed its subject matter jurisdiction, and the remaining columns summarise the approach of the tribunal for each of the six elements: (i) contribution, (ii) duration, (iii) risk, (iv) economic development, (v) profit and return, and (vi) territoriality. The final column includes further observations that do not fit the six other elements.

49. There are some common strands of how investment tribunals approach the notion of "investment": they commonly refer to the interpretive principles in Articles 31 and 32 VCLT when construing the notion of investment; ${ }^{96}$ they frequently invoke the Salini criteria, as well as those of previous decisions; and they emphasise the flexibility of the Salini criteria. ${ }^{97}$

50. Schreuer originally identified five elements in the first edition of his Commentary on the ICSID Convention: (i) a certain duration, (ii) a certain regularity of profit and return, (iii) the assumption of risk, (iv) substantial commitment, and (v) significance for the host State's development. He referred to "characteristics" or "features". 98 The Salini tribunal refers mostly to "criteria", but occasionally also refers to elements and conditions. ${ }^{99}$ This study refers to "elements" of investments. Irrespective of the precise terminology adopted, criteria, characteristics, features or elements are not the same as requirements. ${ }^{100}$ Investment tribunals enjoy some discretion within the bounds that the elements of investment provide. ${ }^{101}$

51. This flexibility of investment tribunals means that the lack of a particular element is not fatal to qualifying a transaction as an investment. ${ }^{102}$ With such flexibility comes some discretion for investment tribunals to decide on the

94 Salini v. Morocco, para. 52.

95 For an overview, see Fakes v. Turkey, paras. 102-4. The tribunal in Fakes v. Turkey argued in favour of three elements: ibid., paras. 107-21.

96 Ambiente Ufficio v. Argentina, paras. 443-54; Poštová banka v. Greece, para. 249.

97 Gavazzi v. Romania, paras. 96-114; Romak v. Uzbekistan, paras. 197-208; Ambiente Ufficio v. Argentina, paras. 475-82; MNSS v. Montenegro, para. 189; Phoenix Action v. Czech Republic, paras. $82-7$.

98 Schreuer, "Commentary on the ICSID Convention: Article 25", n. 71, 373. The third edition of the Commentary uses "characteristics" alongside "criteria": Schill, "Article 25", n. 6, para. 226.

99 Salini v. Morocco, para. 52 ("The criteria to be used for the definition of an investment ... In reading the Convention's preamble, one may add the contribution to the economic development of the host State of the investment as an additional condition. In reality, these various elements may be interdependent").

100 Sole Arbitrator Paulsson in Pantechniki SA Contractors \& Engineers (Greece) v. Republic of Albania, ICSID Case No. ARB/07/21, Award (30 July 2009) [Pantechniki v. Albania], para. 36 ("what has become known as the 'Salini test' . . appears to be a misnomer. It is not so much a test as a list of characteristics of investments.”).

101 Ibid. (calling "the wide margin of appreciation" on investment "unfortunate").

102 Ambiente Ufficio v. Argentina, paras. 475-82. 
Table 2 Elements relevant for investments

\begin{tabular}{|c|c|c|c|c|c|c|c|c|}
\hline \multirow[b]{2}{*}{ Case } & \multicolumn{8}{|c|}{ Elements relevant for investments } \\
\hline & $\begin{array}{l}\text { Subject matter } \\
\text { jurisdiction }\end{array}$ & Dissent & Contribution & Duration & Risk & $\begin{array}{l}\text { Economic } \\
\text { development }\end{array}$ & $\begin{array}{l}\text { Profit and } \\
\text { return }\end{array}$ & Other \\
\hline Mitchell v. DRC & Yes & $\mathrm{x}$ & \multicolumn{6}{|c|}{$\begin{array}{l}\text { N/A, because elements argued by Respondent were not formal requirements of investments; one } \\
\text { ground for annulment was the tribunal's failure to state reasons and manifest excess of powers in } \\
\text { neglecting to explain why there had been an "investment" under Article } 25 \text {, but it was not the } \\
\text { annulment committee's role to consider whether the elements of Article } 25 \text { had been met }\end{array}$} \\
\hline $\begin{array}{l}\text { Mitchell v. DRC } \\
\text { (Annulment Decision) }\end{array}$ & Annulled & & $\mathrm{x}$ & $\mathrm{x}$ & $\mathrm{x}$ & $\mathrm{x}$ & & \\
\hline $\begin{array}{l}\text { Malaysian Historical } \\
\text { Salvors v. Malaysia }\end{array}$ & No & & $\mathrm{x}$ & $\mathrm{x}$ & $\mathrm{x}$ & $\mathrm{x}$ & $\begin{array}{l}\text { Regularity of } \\
\text { profit and } \\
\text { return is } \\
\text { "hallmark" but } \\
\text { its absence in } \\
\text { this case was } \\
\text { immaterial }\end{array}$ & \\
\hline $\begin{array}{l}\text { Malaysian Historical } \\
\text { Salvors v. Malaysia } \\
\text { (Annulment Decision) }\end{array}$ & Annulled & $\mathrm{x}$ & \multicolumn{6}{|c|}{ Rejected Salini criteria (paras. 74-81) } \\
\hline Bayview v. Mexico & No & & \multicolumn{6}{|c|}{ N/A, because the central issue was whether the investors were domestic or foreign } \\
\hline $\begin{array}{l}\text { Biwater Gauff } \\
\text { v. Tanzania }\end{array}$ & Yes & & \multicolumn{6}{|c|}{ Rejected Salini criteria (paras. 310-18) } \\
\hline $\begin{array}{l}\text { Quasar de Valors } \\
\text { v. Russia }\end{array}$ & Yes & & \multicolumn{6}{|c|}{ Only discussion of the BIT's definition (SCC Rules) } \\
\hline
\end{tabular}


Table 2 (cont.)

\begin{tabular}{|c|c|c|c|c|c|c|c|c|}
\hline \multirow[b]{2}{*}{ Case } & \multicolumn{8}{|c|}{ Elements relevant for investments } \\
\hline & $\begin{array}{l}\text { Subject matter } \\
\text { jurisdiction }\end{array}$ & Dissent & Contribution & Duration & Risk & $\begin{array}{l}\text { Economic } \\
\text { development }\end{array}$ & $\begin{array}{l}\text { Profit and } \\
\text { return }\end{array}$ & Other \\
\hline $\begin{array}{l}\text { Quasar de Valors } \\
\text { v. Russia (setting aside } \\
\text { proceedings) }\end{array}$ & $\begin{array}{l}\text { Svea Court of } \\
\text { Appeal set } \\
\text { aside }\end{array}$ & & \multicolumn{6}{|c|}{ N/A (see above) } \\
\hline $\begin{array}{l}\text { Phoenix Action } \\
\text { v. Czech Republic }\end{array}$ & No & & $\mathrm{x}$ & $\mathrm{x}$ & $\mathrm{x}$ & & & $\begin{array}{l}\text { Contribution } \\
\text { to the } \\
\text { economy } \\
\text { (presumed) / } \\
\text { Operation to } \\
\text { develop } \\
\text { economic } \\
\text { activity }\end{array}$ \\
\hline Romak v. Uzbekistan & No & & $\mathrm{x}$ & $\mathrm{x}$ & $\mathrm{x}$ & & & \\
\hline Fakes v. Turkey & No & & $\mathrm{x}$ & $\mathrm{x}$ & $\mathrm{x}$ & & & \\
\hline $\begin{array}{l}\text { Global Trading } \\
\text { Resource v. Ukraine }\end{array}$ & No & & \multicolumn{6}{|c|}{ Manifestly without legal merit because a commercial transaction. No detailed analysis of criteria. } \\
\hline HICEE v. Slovakia & No & $\mathrm{x}$ & \multicolumn{6}{|c|}{$\begin{array}{l}\text { N/A, because the decision centres on relationship between the investor and the investment under the } \\
\text { BIT ("direct/ly") }\end{array}$} \\
\hline Abaclat v. Argentina & Yes & $\mathrm{x}$ & $\mathrm{x}$ & \multicolumn{5}{|c|}{ Rejected Salini criteria (paras. 362-7) } \\
\hline Caratube v. Kazakhstan & $\begin{array}{l}\text { Yes (but } \\
\text { finding only on } \\
\text { BIT, not } \\
\text { Article 25) }\end{array}$ & & $\mathrm{x}$ & & $\mathrm{x}$ & & $\mathrm{x}$ & \\
\hline
\end{tabular}


Table 2 (cont.)

\begin{tabular}{|c|c|c|c|c|c|c|c|c|}
\hline \multirow[b]{2}{*}{ Case } & \multicolumn{8}{|c|}{ Elements relevant for investments } \\
\hline & $\begin{array}{l}\text { Subject matter } \\
\text { jurisdiction }\end{array}$ & Dissent & Contribution & Duration & Risk & $\begin{array}{l}\text { Economic } \\
\text { development }\end{array}$ & $\begin{array}{l}\text { Profit and } \\
\text { return }\end{array}$ & Other \\
\hline $\begin{array}{l}\text { Deutsche Bank v. Sri } \\
\text { Lanka }\end{array}$ & Yes & $\mathrm{x}$ & $\mathrm{x}$ & & $\mathrm{x}$ & & & $\begin{array}{l}\text { Expectation } \\
\text { that the } \\
\text { investment } \\
\text { will be } \\
\text { profitable }\end{array}$ \\
\hline $\begin{array}{l}\text { Standard Chartered } \\
\text { Bank v. Tanzania }\end{array}$ & $\begin{array}{l}\text { No (but finding } \\
\text { only on BIT, } \\
\text { not Article } 25 \text { ) }\end{array}$ & & \multicolumn{6}{|c|}{$\begin{array}{l}\text { N/A, because the decision centres on the relationship between investor and investment under the BIT } \\
\text { ("active relationship") }\end{array}$} \\
\hline $\begin{array}{l}\text { Ambiente } \\
\text { Ufficio v. Argentina }\end{array}$ & Yes & $\mathrm{x}$ & \multicolumn{6}{|c|}{ All five elements of the Salini test, but non-mandatory and flexible (para. 481) } \\
\hline AES v. Kazakhstan & Yes & & \multicolumn{6}{|c|}{ N/A, because the investment character was undisputed } \\
\hline Enkev Beheer v. Poland & $\begin{array}{l}\text { Yes (shares); } \\
\text { no (im/ } \\
\text { movable } \\
\text { property, } \\
\text { retention of } \\
\text { profits and } \\
\text { management of } \\
\text { subsidiary) }\end{array}$ & & \multicolumn{6}{|c|}{ N/A, because no discussion of Article 25 or elements of an "investment" (UNCITRAL case) } \\
\hline Apotex v. USA & No & & \multicolumn{6}{|c|}{ N/A (res judicata) } \\
\hline $\begin{array}{l}\text { Poštová } \\
\text { banka v. Greece }\end{array}$ & $\begin{array}{l}\text { No (under } \\
\text { BIT), }\end{array}$ & & $\mathrm{X}$ & $\mathrm{X}$ & $\mathrm{x}$ & & & \\
\hline
\end{tabular}




\begin{tabular}{|c|c|c|c|c|c|c|c|c|c|}
\hline \multirow[b]{2}{*}{ Case } & \multicolumn{9}{|c|}{ Elements relevant for investments } \\
\hline & $\begin{array}{l}\text { Subject matter } \\
\text { jurisdiction }\end{array}$ & Dissent & Contribution & Duration & Risk & $\begin{array}{l}\text { Economic } \\
\text { development }\end{array}$ & $\begin{array}{l}\text { Profit and } \\
\text { return }\end{array}$ & Territoriality & Other \\
\hline & $\begin{array}{l}\text { No (Art. } 25, \\
2: 1, \text { obiter) }\end{array}$ & & & & & & & & \\
\hline $\begin{array}{l}\text { Poštová } \\
\text { banka v. Greece } \\
\text { (Annulment Decision) }\end{array}$ & Upheld & $\begin{array}{l}\mathrm{x} \\
\text { (obiter) }\end{array}$ & \multicolumn{7}{|c|}{ N/A, because no discussion of Article 25, no consideration of Art 25 necessary (para. 159) } \\
\hline Gavazzi v. Romania & Yes & & $\mathrm{x}$ & $\mathrm{x}$ & $\mathrm{x}$ & $\begin{array}{l}\text { Not } \\
\text { mandatory }\end{array}$ & & & \\
\hline MNSS v. Montenegro & Yes & & $\mathrm{x}$ & $\mathrm{x}$ & $\mathrm{x}$ & & & & $\begin{array}{l}\text { Contribution } \\
\text { to the } \\
\text { economy } \\
\text { (in principle } \\
\text { presumed) }\end{array}$ \\
\hline Sum & & & 11 & 8 & 10 & 2 & 1 & 0 & 3 \\
\hline
\end{tabular}

i The tribunal in Phoenix Action v. Czech Republic also held that the transaction must be in accordance with the laws of the host State and bona fide to qualify as an investment. There is a distinction between the qualification of an "investment" (for which good faith is irrelevant) and the protection and coverage of the ICSID Convention (for which good faith is relevant). On the illegality of investments and abuse of rights, see J. E. Viñuales, "Defence Arguments in Investment Arbitration" (2020) 18 ICSID Rep 9, 30-4, 42-6. In particular, note the different consequences of abuse of rights when (i) a tribunal rejects the qualification as "investment" itself, as in Phoenix Action v. Czech Republic, or (ii) the claim is inadmissible because protection of the treaty is rejected as in Philip Morris v. Australia. See ibid., 44. 
contours of the word "investment". A flexible approach is in keeping with Schreuer's admonition that the characteristics "should not necessarily be understood as jurisdictional requirements but merely as typical characteristics of investments under the Convention". ${ }^{103}$ The decisions in this volume illustrate the degrees of freedom that investment tribunals enjoy when it comes to defining the notion of investment: ${ }^{104}$ for example, tribunals rejected the investment character of the delivery of wheat ${ }^{105}$ or of poultry, ${ }^{106}$ but held that that an oil hedging agreement amounted to an investment. ${ }^{107}$

52. For those awards covered in this volume where investment tribunals denied jurisdiction for lack of an "investment", Table 3 summarises the elements on which these tribunals reached this conclusion. The awards are in ascending chronological order. Five out of 25 decisions reported in this volume fall into this category (the only ad hoc annulment committee that annulled an award for lack of an investment, Mitchell v. DRC, is not shown because the committee by definition did not make any findings on investment; it merely annulled the tribunal's award). Column 2 indicates whether the tribunal affirmed its subject matter jurisdiction, and an " $\mathrm{x}$ " in columns 3 to 8 indicates that the tribunal declined the investment character of the transaction based on the absence of the criterion concerned: contribution (column 3), duration (column 4), risk (column 5), economic development (column 6), profit and return (column 7) and territoriality (column 8).

\section{i. Contribution}

53. Ten out of the 25 decisions in this volume expressly affirmed that contribution was an element of an investment under Article 25 ICSID Convention. ${ }^{108}$ Only one tribunal (Biwater Gauff) and one ad hoc annulment committee (Malaysian Historical Salvors) expressly rejected this element of an investment (as part of their rejection of the Salini criteria more generally). ${ }^{109}$ The need for a contribution

103 Schreuer, "Commentary on the ICSID Convention: Article 25", n. 71, para. 122; "Article 25" in C. Schreuer, The ICSID Convention: A Commentary (Cambridge University Press, 2nd edn, 2009) [Schreuer, "Article 25" 2nd edn], para. 153; M. Waibel, "Investment Arbitration: Jurisdiction and Admissibility" in M. Bungenberg, J. Griebel, S. Hobe and A. Reinisch (eds.) International Investment Law: A Handbook (Nomos, 2015), 1261-1336, paras. 193-4.

104 Sattorova, n. 4, 273 (referring to the "elasticity with which the outer limits of investor-state arbitration may be drawn by different panels").

105 Romak v. Uzbekistan, para. 242. $\quad{ }^{106}$ Global Trading Resource v. Ukraine, paras. 36-9, 58.

107 Deutsche Bank v. Sri Lanka, para. 310.

108 Three decisions of annulment committees and one set-aside proceeding are also reported in the volume. However, these bodies are only empowered to decide whether one or several of the grounds of annulment/set-aside applies to an award; they do not decide whether a transaction amounts to an investment. Nonetheless, the annulment committees in Mitchell v. DRC Annulment and in Malaysian Historical Salvors Sdn, Bhd v. Government of Malaysia, ICSID Case No. ARB/05/10, Decision on the Application for Annulment (16 April 2009) [Malaysian Historical Salvors v. Malaysia Annulment] have weighed in on the discussion of the elements of an investment (see Table 2).

109 Malaysian Historical Salvors v. Malaysia Annulment, paras. 74-81; Biwater Gauff (Tanzania) Ltd v. United Republic of Tanzania, ICSID Case No. ARB/05/22, Award (25 July 2008) [Biwater Gauff v. Tanzania], paras. 310-18. In the remaining 12 decisions, contribution was not material (e.g. because the tribunal decided purely based on the applicable BIT). 
Table 3 Elements of investment based on which tribunals denied jurisdiction

\begin{tabular}{|c|c|c|c|c|c|c|c|}
\hline \multirow[b]{2}{*}{ Case } & \multicolumn{7}{|c|}{ Elements of investment based on which tribunals denied jurisdiction } \\
\hline & $\begin{array}{l}\text { Subject matter } \\
\text { jurisdiction }\end{array}$ & Contribution & Duration & Risk & $\begin{array}{l}\text { Economic } \\
\text { development }\end{array}$ & $\begin{array}{l}\text { Profit and } \\
\text { return }\end{array}$ & Territoriality \\
\hline $\begin{array}{l}\text { Malaysian Historical Salvors } \\
\text { v. Malaysia }\end{array}$ & No & & & & $\mathrm{x}$ & & \\
\hline Phoenix Action v. Czech Republic & No & \multicolumn{6}{|c|}{$\begin{array}{l}\text { See para. } 73 \text {. The tribunal rejected jurisdiction because the economic transaction was not } \\
\text { bona fide. }\end{array}$} \\
\hline Romak v. Uzbekistan & No & $\mathrm{x}$ & $\mathrm{x}$ & $\mathrm{x}$ & & & \\
\hline Fakes v. Turkey & No & $\mathrm{x}$ & $\mathrm{x}$ & $\mathrm{x}$ & & & \\
\hline Poštová banka v. Greece & $\begin{array}{l}\text { No (under BIT), } \\
\text { No (Art. 25, 2:1, obiter) }\end{array}$ & $\mathrm{x}$ & & $\mathrm{x}$ & & & \\
\hline Sum & & 3 & 2 & 3 & 1 & 0 & 0 \\
\hline
\end{tabular}


was one of two elements that the Abaclat tribunal accepted, even though it rejected three other Salini criteria. ${ }^{110}$

54. Four investment tribunals concluded that there was no investment, based on the absence of a contribution. First, in Romak v. Uzbekistan, a tribunal operating under the UNCITRAL Rules held that a supply contract for the delivery of 50,000 tons of wheat (of which it delivered around 40,600 tons) did not amount to an investment - nor did an arbitral award associated with it - because a mere delivery did not amount to a contribution. While the tribunal defined contribution broadly as "any dedication of resources that has economic value", "a mere transfer of title over goods" was insufficient for an investment to exist. ${ }^{111}$ The supply contract envisaged immediate performance at the market rate.

55. Second, in Fakes v. Turkey, the tribunal found that, because the claimant had never become the legal owner of shares in the second-largest mobile phone company in Turkey, the claimant had not made a contribution. ${ }^{112}$ Third, in Poštová banka v. Greece, the tribunal in an obiter dictum considered that Greek government bonds held by the claimants did not involve a contribution (the ratio of the award was based exclusively on the definition of investment in the investment treaty). According to the tribunal, there was no creation of value, but only an exchange of value akin to a sale because the funds served Greece's budgetary needs, particularly the refinancing of its existing debt. ${ }^{113}$

56. Fourth, in Standard Chartered Bank v. Tanzania, the tribunal found that the claimant was merely a passive owner and had not made the required active contribution under the investment treaty. ${ }^{114}$ A subsidiary of the British claimant bank in Hong Kong was owed a debt by a Tanzanian power company. This debt originally arose from a power purchase agreement for the construction and operating of a power plant in Tanzania. The Hong Kong subsidiary had acquired the debt from a Malaysian company charged with reducing non-performing loans from the Malaysian financial system. Even though the British bank was indirectly linked to the debt via its subsidiary, no British company had made a contribution in Tanzania's territory. "Owning" or "holding" the purported investment was insufficient. It was necessary for the claimant to take on an active role, such as directing the purchase of the debt (for which there was no evidence).

57. In HICEE v. Slovakia, the claimant held indirect, structured investments in two Slovak health insurance companies mediated by a holding company that was also incorporated in Slovakia. The holding company was a direct investment, but the holding company's shares in the two local insurance companies were only indirect investments of the claimants. Based on the specific language of the investment treaty, and after resolving the ambiguity of this language using the travaux préparatoires, ${ }^{115}$ the tribunal found that the claims with respect to alleged

\footnotetext{
110 Abaclat v. Argentina, paras. 363-6. 111 Romak v. Uzbekistan, paras. 32-47, 209-22.

112 Fakes v. Turkey, para. $141 . \quad 113$ Poštová banka v. Greece, paras. 361-3.

114 Standard Chartered Bank v. United Republic of Tanzania, ICSID Case No. ARB/10/12, Award, 2 November 2012 [Standard Chartered Bank v. Tanzania], paras. 196-201.

115 E. Shirlow and M. Waibel, "A Sliding Scale Approach to Travaux in Treaty Interpretation: The Case of Investment Treaties" (2021) British Yearbook of International Law (forthcoming).
} 
damage to the indirect investment, held by a Slovak company, were inadmissible due to the way in which the investment was made. ${ }^{116}$ These shares were not "an investment of investors of the other Contracting Party", but an investment by one Slovak entity in two other Slovak entities. ${ }^{117}$

58. Awards that focus on passive investments - such as Standard Chartered Bank - and structured, indirect investments - such as HICEE - sit at the intersection of subject matter and personal jurisdiction. ${ }^{118}$ The Standard Chartered Bank award itself is ambiguous on whether disputes about investments "of" investors pertain to subject matter jurisdiction. ${ }^{119}$ On the one hand, the tribunal's test of whether there was an "active relationship between the investor and the investment" 120 and the tribunal's holding "that the investor should have 'made' the investment in an active sense" ${ }^{121}$ suggests personal jurisdiction. ${ }^{122}$ On the other hand, the tribunal was not concerned with characteristics of the investment typically associated with jurisdiction, such as nationality, but with how the particular claimant established the investment. Even though the focus on the "activity of investing" "123 requires an enquiry into the role of the claimant, this approach is rooted in the unity of an investment: ${ }^{124}$ the manner in which the contribution is made (or whether it is made at all) forms part of the process or unity of a putative investment (which is best conceived as an action, activity or process, rather than a static asset) and is thus an issue of subject matter jurisdiction rather than personal jurisdiction. $^{125}$

116 HICEE v. Slovakia, paras. 146-7.

117 Ibid., para. 145. Cf. G. Bottini, Admissibility of Shareholder Claims under Investment Treaties (Cambridge University Press, 2020), 145.

118 On passive investments, see further J. Ho, "Passive Investments" (2020) 34(3) ICSID Review Foreign Investment Law Journal 1. On structured, indirect investments, see J. Baumgartner, Treaty Shopping in International Investment Law (Oxford University Press, 2016), Ch. 5.

119 Baumgartner, n. 118, 158 ("Standard Chartered Bank arguably raises more questions than it actually answers, the key question being, as also asked by that tribunal, where the line is to be drawn between a protected 'active' (indirect) investment and an unprotected 'passive' (indirect) investment').

${ }^{120}$ Standard Chartered Bank v. Tanzania, para. 230; see also paras. 197-8 (describing its inquiry as whether "Claimant took actions concerning the Tanzanian Loans that would confer the status of investor" and "Claimant's status as a treaty investor so that the Loans may be considered investments 'of' Claimant").

121 Ibid., para. 260.

122 Cf. also Alapli Elektrik BV v. Republic of Turkey, ICSID Case No. ARB/08/13, Award (13 July 2012) [Alapli v. Turkey], paras. 358, 360 (arbitrator Park, who was the presiding arbitrator in Standard Chartered Bank, in his individual majority opinion explains that passive investments do not qualify for treaty protection as a result of which investors are protected; at the same time, he regards the relationship between putative investor and investment as one that is concerned with the "activity of investing" and "an action transferring something of value" - suggesting subject matter jurisdiction).

123 Standard Chartered Bank v. Tanzania, paras. 197-8 (referring to "process" and "actions"); Alapli v. Turkey, para. 358.

124 C. Schreuer, "The unity of an investment", 19 ICSID Reports 3; cf. also Sattorova, n. 4 (adopting a process-oriented approach to subject matter jurisdiction).

${ }_{125}$ An UNCITRAL tribunal distinguished Standard Chartered Bank based on a crucial difference in the wording of the applicable investment treaty, Flemingo DutyFree Shop Private Limited v. Republic of Poland, PCA Case No. 2014-11, Award (12 August 2016). The investment treaty referred not just to investments "established" but also to those later "acquired", with the result that acquisition of investments already made counted as an investment. 
59. The issue of an investment "of" an investor reflects the same concerns as the Salini criterion of contribution to the development of the host State (see below). ${ }^{126}$ Yet, the focus is on the upstream source of the contribution, rather than on the downstream benefit for development. At both ends of the process, however, the quality of the contribution is at stake - subject matter jurisdiction - rather than the characteristics of the investor (personal jurisdiction). ${ }^{127}$

\section{ii. Duration}

60. Eight out of the 25 decisions in this volume expressly affirmed that duration was an element of an investment - which is two decisions fewer than for the first element of contribution above. Four tribunals (Abaclat; Biwater Gauff; Caratube and Deutsche Bank) and one ad hoc annulment committee (Malaysian Historical Salvors) expressly rejected this element (as part of their rejection of the Salini criteria more generally). ${ }^{128}$ The element is rarely crucial or decisive: in only two of the reported awards (Romak; Saba Fakes) did tribunals find that the lack of duration was a reason why the transaction did not amount to an investment but in both cases alongside a lack of contribution and the lack of risk. No investment tribunal thus far has found that a transaction does not qualify as an investment based solely on the missing long-term transfer of financial resources.

61. First, in Romak v. Uzbekistan, the tribunal considered that a contract for supplying 50,000 tons of wheat over a five-month period, coupled with the lack of past or future relationship, meant that this was a one-time transaction - rather than an investment with a relationship of longer duration between the claimant and the host State. At the same time, it underscored there was no "fixed minimum duration that determines whether assets qualify as investments", and that "short-term projects" could so qualify in light of all the circumstances of the transaction. ${ }^{129}$ Second, in Fakes v. Turkey, the tribunal found that because the claimant had never become the legal owner of shares in the second-largest mobile phone company in Turkey, the criterion of a certain duration was not met. ${ }^{130}$

\section{iii. Risk}

62. Nine out of the 25 decisions in this volume expressly affirmed that risk was an element of investments. Only two tribunals (Abaclat; Biwater Gauff) and one ad hoc annulment committee (Malaysian Historical Salvors) expressly rejected this element for an investment (as part of their rejection of the Salini criteria more generally). ${ }^{131}$

\footnotetext{
126 South American Silver Limited (Bermuda) v. Plurinational State of Bolivia, PCA Case No. 201315, Award (22 November 2018), paras. 339-40.

127 Cf. also Schill, "Article 25", n. 6, paras. 362-8 (referring to "active" contribution).

128 In the remaining 12 decisions, the duration element was not material (e.g. because the tribunal decided based on the applicable BIT alone).

129 Romak v. Uzbekistan, paras. 223-7. ${ }^{130}$ Fakes v. Turkey, para. 141.

131 In the remaining 13 decisions, risk was not material (e.g. because the tribunal decided purely based on the applicable BIT).
} 
63. Views among investment tribunals and commentators differ as to the kind of risk that is needed for a transaction to qualify as an investment. Some tribunals, such as the Malaysian Historical Salvors annulment committee, consider that any kind of risk, such as the mere risk that the host State fails to perform a contract, suffices. ${ }^{132}$ A second view is that there needs to be sharing of operational risk between the investor and the host State - a view that the tribunals in the following awards adopted. This is sometimes expressly linked to the need for a commercial venture in the host country. ${ }^{133} \mathrm{~A}$ third view is that the distinction between commercial risk, on the one hand, and investment/operational risk, on the other hand, is irrelevant. Investment treaties protect only against sovereign risk, a type of risk that is unrelated to both commercial and investment risk.

64. In Romak v. Uzbekistan, the tribunal distinguished between general business risk and investment risk:

An "investment risk" entails a different kind of alea, a situation in which the investor cannot be sure of a return on his investment, and may not know the amount he will end up spending, even if all relevant counterparties discharge their contractual obligations. Where there is "risk" of this sort, the investor simply cannot predict the outcome of the transaction. ${ }^{134}$

65. The tribunal found that Romak had assumed only general business risk (which the tribunal also referred to "as pure commercial, counterparty risk" because the only risk for the claimant was the risk of non-payment for the delivery of wheat. The risk of non-performance was common to all forms of activity but did not suffice for purposes of qualifying a transaction as an investment. ${ }^{136}$

66. The tribunal in Poštová banka referred to Romak's distinction between general business risk (commercial/default risk) and investment risk. Because the claimants transferred funds to Greece that were used for repaying existing debt, rather than for a commercial undertaking, interests in Greek government bonds carried no investment risk. ${ }^{137}$ The tribunal explained further:

Under an "objective" test, the element of risk is essential and cannot be analysed in isolation. Indeed any economic transaction - it could even be said any human activity entails some element of risk. Risk is inherent in life and cannot per se qualify what is an investment ... In other words, under an "objective" approach, an investment risk would be an operational risk and not a commercial risk or a sovereign risk. ${ }^{138}$

67. Risk is the element of investment which features prominently in the cases distinguishing commercial transactions from investments (see below). Six of eight

132 Pahis, "Investment Misconceived", n. 45, 110-12.

133 Waibel, "Treaty Interpretation", n. 34, para. 215 (linking risk sharing and association with a commercial undertaking); Waibel, "Opening Pandora's Box", n. 2, 723-6.

134 Romak v. Uzbekistan, para. 230; Joy Mining v. Egypt, para. 57.

135 Romak v. Uzbekistan, para. 229. ${ }^{136}$ Romak v. Uzbekistan, paras. 228-32.

137 Poštová banka v. Greece, para. 364.

138 Poštová banka v. Greece, paras. 367-9. For criticism of the operational risk theory, see Pahis, "Investment Misconceived", n. 45, 110-12. 
decisions that Pahis analyses differentiate commercial transactions from investments based on the character of the risk, among other Salini criteria. ${ }^{139}$

iv. (Contribution to the) economic development of the host State

68. Of the 25 decisions reported in this volume, only one annulled award (Malaysian Historical Salvors) and one annulment decision (Mitchell v. DRC) consider that contribution to the economic development of the host State was a criterion of investment. Five tribunals expressly rejected or have not retained contribution to economic development of the host State as a necessary criterion of investment. ${ }^{140}$ Douglas considers that contribution to the host State's economic development (alongside duration) "generates too much subjectivity". ${ }^{141}$ In L.E.S.I. v. Algeria, the tribunal held that this element was implicit in contribution, duration and risk. $^{142}$

69. The tribunal in Fakes stated that:

Those tribunals that have considered this element as a separate requirement for the definition of an investment, such as the Salini Tribunal, have mainly relied on the preamble to the ICSID Convention to support their conclusions. The present Tribunal observes that while the preamble refers to the "need for international cooperation for economic development," it would be excessive to attribute to this reference a meaning and function that is not obviously apparent from its wording. ${ }^{143}$

70. The tribunal in Deutsche Bank v. Sri Lanka rejected contribution to economic development as a standalone element under Article 25 ICSID Convention in relation to an oil hedge sold by a European bank to a State-owned company in Sri Lanka and governed by English law. According to the tribunal, this element had been "discredited" and was generally considered "unworkable owing to its subjective nature". ${ }^{144}$ Arbitrator Ali Khan, dissenting, considered that "the substantial commitment or contribution by the Claimant must be made for economic

139 Pahis, "Investment Misconceived", n. 45, 94 and 110-12. The six cases are Joy Mining v. Egypt, Malaysian Historical Salvors v. Malaysia, Romak v. Uzbekistan, Alps Finance and Trade AG v. Slovak Republic, UNCITRAL, Award (5 March 2011) [Alps Finance v. Slovak Republic], Nova Scotia Power Incorporated v. Bolivarian Republic of Venezuela, ICSID Case No. ARB(AF)/11/1, Award (30 April 2014) [Nova Scotia Power v. Venezuela], and Poštová banka v. Greece.

140 Gavazzi v. Romania, paras. 112-14 ("a contribution to an actual economic development of the host state is not always a conditio sine qua non to qualify as investment under Article 25 of the ICSID Convention"); Deutsche Bank v. Sri Lanka, paras. 293-5; MNSS v. Montenegro, para. 189; Phoenix Action v. Czech Republic, paras. 82-7; Fakes v. Turkey, para. 111.

141 Z. Douglas, The International Law of Investment Claims (Cambridge University Press, 2009), para. 407, cited approvingly by Sole Arbitrator Paulsson in Pantechniki v. Albania, para. 36; Deutsche Bank v. Sri Lanka, para. 306 ("whether or not a commitment of capital or resources ultimately proves to have contributed to the economic development of the host State can often be a matter of appreciation and can generate a wide spectrum of reasonable opinions"); S. Manciaux, "The Notion of Investment: New Controversies" (2008) 9 Journal of World Investment and Trade 6, 16.

142 L.E.S.I. S.p.A. et ASTALDI S.p.A. v. République algérienne démocratique et populaire, ICSID Case No. ARB/05/3, Decision (12 July 2006), para. 72(iv).

143 Fakes v. Turkey, para. 111. $\quad{ }^{144}$ Deutsche Bank v. Sri Lanka, para. 306. 
development in the host State", and found that there was "no contribution or commitment [in this case], let alone any substantial contribution". ${ }^{145}$

71. By contrast, in Mitchell v. DRC, the annulment committee found contribution to the economic development of the host State was "essential". ${ }^{146}$ This fourth criterion of an investment was the decisive element in this case. The annulment committee explained that

the parameter of contributing to the economic development of the host State has always been taken into account, explicitly or implicitly, by ICSID arbitral tribunals in the context of their reasoning in applying the Convention, and quite independently from any provisions of agreements between parties or the relevant bilateral treaty. ${ }^{147}$

72. At the same time, the Mitchell committee underscored that contribution to economic development was a flexible criterion and that investment tribunals were not required to carry out an empirical assessment:

[It] does not mean that this contribution must always be sizable or successful; and, of course, ICSID tribunals do not have to evaluate the real contribution of the operation in question. It suffices for the operation to contribute in one way or another to the economic development of the host State, and this concept of economic development is, in any event, extremely broad but also variable depending on the case. ${ }^{148}$

73. The tribunals in Phoenix Action v. Czech Republic and MNSS v. Montenegro chose a third - "less ambitious" "149 - approach of reframing the contribution to economic development of the host State: both tribunals opted for "a contribution to the economy" of the host State, instead of a contribution to "economic development" as the latter was "impossible to ascertain" given "highly divergent views on what constitutes 'development"". ${ }^{150}$ A contribution to the economy could be presumed because it was "inherent in the mere concept of investment", as reflected in the three main Salini criteria: contribution, duration and risk. ${ }^{151}$

74. The claimant's shares in two Czech companies that traded ferroalloys contributed to the Czech economy, but they did not amount to an investment because the only goal of the purported investment was to rearrange assets within the claimant's family of companies to transform a domestic dispute into an international dispute. The tribunal gave weight to the "strong indicia that no economic activity in the market place was either performed or even intended by Phoenix. No business plan, no program of re-financing, no economic objectives were ever presented, no real valuation of the economic transactions."152 Thus, the claimant hoped to gain access to ICSID arbitration to which the initial claimant

145 Deutsche Bank AG v. Democratic Socialist Republic of Sri Lanka, ICSID Case No. ARB/09/2, Dissenting Opinion of Makhdoom Ali Khan (23 October 2012) [Deutsche Bank v. Sri Lanka Dissent], paras. 52, 62 .

146 Mitchell v. DRC Annulment, para. 33. 147 Ibid., para. 29.

148 Ibid., para. 33.

149 MNSS v. Montenegro, para. 189 (citing Phoenix Action v. Czech Republic, para. 85).

150 Phoenix Action v. Czech Republic, para. 85. ${ }_{151}^{15}$ Ibid.

152 Phoenix Action v. Czech Republic, para. 140. 
was not entitled. ${ }^{153}$ The claimant did not act in good faith and committed an abuse of rights.

\section{v. Profit and return}

75. No tribunal viewed profit and return as an element of an investment under Article 25 ICSID Convention. Only one tribunal (Caratube) found that profit and return was an element of investment under the investment treaty. A further award, Malaysian Historical Salvors, that was annulled on different grounds, considered regularity of profit and return a "hallmark" of an investment but that the absence of this element was immaterial in the case of the salvage operation of a vessel sunk in 1817 in Malaysian territorial waters. ${ }^{154}$ Eleven tribunals failed to include this element in their definition of investment under Article 25 ICSID Convention. ${ }^{155}$

76. This element, one of Schreuer's original five typical characteristics, "did not, in general, pose any problems". ${ }^{156}$ In Biwater Gauff v. Tanzania, the Respondent argued that due to the project being a "loss leader", it could not qualify as investment. But the tribunal rejected this argument. ${ }^{157}$ It recommended a "more flexible and pragmatic approach", a holistic assessment of all the circumstances rather than construing the Salini criteria as requirements in one form or another. ${ }^{158}$

\section{vi. Territoriality}

77. No tribunal viewed a territorial link as an element of investment under Article 25 ICSID Convention. Thirteen decisions reported in this volume omit a territorial element from their definition of investment under Article 25 ICSID Convention. ${ }^{159}$ It is surprising that tribunals do not regard it as an element of investment under Article 25 that the investment be physically located in the host country. That said, some dissenting opinions recognise a territorial element in disputes concerning financial instruments. ${ }^{160}$

\footnotetext{
153 Ibid.

154 Malaysian Historical Salvors v. Malaysia, para. 108 ("This particular hallmark did not feature in the so-called Salini test, although it is mentioned in Schreuer. There is no regularity of profits and returns on the present facts. However, the Tribunal accepts the Claimant's answer in response, which is that this criterion may not always be decisive").

155 In the remaining 12 decisions, profit and return was not relevant (e.g. because the tribunal decided purely based on the applicable BIT, for instance in Caratube).

156 Schreuer, "Article 25" 2nd edn, n. 103, para. 161 relying on Joy Mining v. Egypt, para. 57; Jan de Nul N.V. and Dredging International N.V. v. Arab Republic of Egypt, ICSID Case No. ARB/04/13, Decision on Jurisdiction (16 June 2006), para. 92; Helnan International Hotels A/S v. Arab Republic of Egypt, ICSID Case No. ARB/05/19, Decision on Jurisdiction (17 October 2006), para. 77.

157 Biwater Gauff v. Tanzania, paras. 319-21.

158 Ibid., para. 316 (cited with approval in Malaysian Historical Salvors v. Malaysia Annulment, para. 79); cf. also RSM Production Corporation v. Grenada, ICSID Case No. ARB/05/14, Award (13 March 2009), paras. 240-1 (flexible benchmarks or yardsticks).

159 In the remaining 12 decisions, a territorial link was not material (e.g. because the tribunal decided purely based on the applicable BIT), such as Quasar de Valors SICAV SA, Orgor de Valores SICAV S.A, GBI 9000 SICAV SA and Alos 34 S.L. v. Russian Federation, SCC Case No. 24/2007, Award on Preliminary Objections (20 March 2009) [Quasar de Valors v. Russia] (considering American Depository Receipts).

160 See e.g. Abaclat v. Argentina Dissent, paras. 73-4; Deutsche Bank v. Sri Lanka Dissent, para. 37. See further Z. Douglas, "Property, Investment and the Scope of Investment Protection Obligations" in
} 
78. When investment tribunals do discuss the territorial link, it is by reference to language in the applicable investment treaty. References to "in the territory" in investment treaties are common. Two NAFTA awards under the ICSID Additional Facility Rules reported in this volume (Apotex and Bayview) discuss the territorial element of investment exclusively based on Chapter 11 NAFTA and without reference to Article 25 ICSID Convention.

79. An early award that adopted a very broad reading of territoriality was Fedax v. Venezuela. It sufficed that "funds were made available . . . to the beneficiary of the credit [i.e. Venezuela] so as to finance [Venezuela's] various governmental needs". ${ }^{161}$ The Fedax approach on this issue has influenced later investment tribunals, particularly in the three Argentine bond cases. ${ }^{162}$

80. In Abaclat v. Argentina, the territorial element was important because security entitlements in Argentine sovereign bonds governed by an external law and subject to the jurisdiction of external courts were at issue. The Abaclat tribunal considered that the situs of the debt was in Argentina because what mattered was for whose benefit the funds were used. Because the funds were available to Argentina and supported Argentina's economic development, the territorial element was satisfied. ${ }^{163}$

81. The tribunal in Ambiente Ufficio adopted a similar approach regarding the territorial element in the BIT. It considered that the "decisive criterion cannot be whether [the bonds] are physically located in Argentina", as they differed qualitatively from "physical investments". ${ }^{164}$ The State that benefited from the transaction was automatically the one in whose territory the transaction has been made: "to assess where an investment was made, the criterion must be to whose economic development an investment contributed". 165

82. According to the Romak tribunal, the mention of "territory" in the preamble of the applicable investment treaty does not warrant an independent element of territoriality. Instead, the tribunal analysed territoriality "in light of" the three

Z. Douglas, J. Pauwelyn and J. E. Viñuales (eds.), The Foundations of International Investment Law: Bringing Theory into Practice (Oxford University Press, 2014), 363-406; M. Waibel, Sovereign Defaults before International Courts and Tribunals (Cambridge University Press, 2011), 238-42; Waibel, "Jurisdiction and Admissibility", n. 103, paras. 144-5 (premise that the investor is physically present in the host country and falls under the control of the host country's legislative, executive and judicial power).

${ }_{161}$ Fedax v. Venezuela, para. 41. Cf. Ambiente Ufficio v. Argentina, para. 504.

162 Cf. also Quasar de Valors v. Russia, para. 144.

163 Abaclat v. Argentina, paras. 374-9. Cf. Abaclat v. Argentina Dissent, paras. 74ff, developing legal and material criteria for establishing the situs of an investment, which arbitrator Torres Bernárdez endorsed both in Abaclat and Others v. Argentine Republic, ICSID Case No. ARB/07/5, Declaration appended to the Award by Santiago Torres Bernárdez (29 December 2016) and in Ambiente Ufficio SpA and Others v. Argentine Republic, ICSID Case No. ARB/08/9, Dissenting Opinion of Santiago Torres Bernárdez (2 May 2013) [Ambiente Ufficio v. Argentina Dissent], 298ff. Cf. also C. Lévesque, "Abaclat and Others v Argentine Republic: The Definition of Investment" (2012) 27 ICSID Review - Foreign Investment Law Journal, 247-54, 251-3 (affirming the territorial element, noting that the majority made "quite a leap of logic and faith by assuming that funds made available to Argentina must be considered to have contributed to the economic development of that country").

164 Ambiente Ufficio v. Argentina, para. 498 (citing Abaclat v. Argentina, para. 502).

165 Ambiente Ufficio v. Argentina, paras. 496-510. 
elements that it identified as inherent in the meaning of investments under the BIT for UNCITRAL and ICSID proceedings: contribution, duration and risk. ${ }^{166}$ The tribunal explained:

Although the BIT contains numerous references to the "territory" of the Contracting States, the Arbitral Tribunal notes that Article 1(2) of the BIT, which defines the term "investments," does not. The Arbitral Tribunal can identify no treaty provision requiring that the investor's contribution physically take place within the boundaries of the host State to trigger substantive protection ... unless contracting States have made "territoriality" an express pre-requisite for treaty coverage (which is not the case in the BIT), references to "territory" normally refer to the benefit that the host State expects to derive from the investment. ${ }^{167}$

83. In Bayview, a NAFTA tribunal operating under ICSID Additional Facility Rules considered rights of the claimants in the United States to extract water flowing through the Rio Grande/Río Bravo. ${ }^{168}$ They contended that these rights amounted to investments in Mexico. The tribunal's analysis focuses on whether claimants had an investment in Mexico. ${ }^{169}$ The tribunal declined jurisdiction because the claimants' investments were physically located in the United States rather than in the host State. The claimants had no personal property rights in the water flowing through the river on Mexican territory. ${ }^{170}$

84. In Apotex, another NAFTA tribunal operating under ICSID Additional Facility Rules considered obiter in response to the host State's alternative argument that the investment must be "in the territory" - though this was immaterial because the tribunal would have reached the same conclusion. The tribunal held that marketing authorisations by the US Food and Drug Administration were not an investment in US territory "particularly" because of the lack of a physical presence and the absence of tax payments. ${ }^{171}$

vii. Investments in accordance with the laws of the host State or good faith investments

85. Tribunals have adopted two divergent approaches on whether the legality or the good faith character of an investment pertained to the definition of investment. There is a distinction between the qualification of an "investment" (for which legality/good faith is irrelevant) and the protection and coverage of the ICSID

\footnotetext{
166 Romak v. Uzbekistan, paras. 173-237. ${ }^{167}$ Ibid., para. 237.

168 The Mexico-US boundary is the centre of the normal channel of the Rio Grande/Río Bravo. See Convention between the United States of America and the United States of Mexico on Boundary Waters (adopted 1 March 1889, entered into force 24 December 1890) USTS 232; Treaty between the United States of America and Mexico relating to the Utilization of Waters of the Colorado and Tijuana Rivers and of the Rio Grande (Rio Bravo) from Fort Quitman, Texas, to the Gulf of Mexico, and Supplementary Protocol (treaty signed 3 February 1944, protocol signed 14 November 1944, entered into force 8 November 1945) 3 UNTS 313, USTS 994; and The Chamizal Case (Mexico v. United States), Award (15 June 1911) XI UNRIAA 309 (considering an exogenous shift in the course of the river).

169 Bayview Irrigation District et al. v. United Mexican States, ICSID Case No. ARB(AF)/05/1, Award

(19 June 2007), paras. 81-124.

170 Ibid., paras. 25-9, 109-17.

171 Apotex Holdings Inc. and Apotex Inc. v. United States of America, ICSID Case No. ARB(AF)/12/1, Award (25 August 2014), para. 7.62.
} 
Convention (for which legality/good faith are relevant). ${ }^{172}$ The first concerns jurisdiction, the second admissibility. ${ }^{173}$ Whereas legality as a matter of definition concerns only jurisdiction, legality as a matter of coverage can concern either jurisdiction - if the definition of investment is met but a further requirement ratione materiae for the perimeter or scope of the treaty is not met - or admissibility - if the tribunal deems jurisdictional hurdles met but that it should not use its adjudicative power. The tribunal in Fakes stated:

the principles of good faith and legality cannot be incorporated into the definition of Article 25(1) of the ICSID Convention without doing violence to the language of the ICSID Convention. ${ }^{174}$

86. By contrast, the tribunal in Phoenix Action v. Czech Republic held that ICSID tribunals only have jurisdiction with respect to transactions that are in accordance with host State law and are bona fide investments. ${ }^{175}$ While the investor had not breached Czech law on the facts and thus complied with the first requirement, it made the investment not to engage in economic activity, but to transform an existing domestic dispute into an international one. The tribunal thus rejected its jurisdiction for lack of the second requirement (no bona fide investment). The consequences of the investor's lack of good faith (abuse of rights) differ depending on whether: (i) a tribunal rejects the qualification as "investment" itself, as in Phoenix (no jurisdiction); or (ii) protection of the treaty is rejected, as in Philip Morris v. Australia (the claim is inadmissible). ${ }^{176}$

\section{The new objectivism: objective in name only}

87. A second approach contends that the meaning of investment in Article 25 ICSID Convention is almost limitless. This new objectivism, of which Julian Mortenson is a leading exponent, argues against any positive elements for investment such as the Salini ones examined above. Mortenson construes investment as broadly as possible with "near-total deference to state definitions of "investment"" in investment treaties, ${ }^{177}$ excluding only "facially absurd" definitions. ${ }^{178} \mathrm{He}$ concludes that "ICSID has jurisdiction over any plausibly economic asset or activity". ${ }^{179} \mathrm{He}$ gives the following example of an excluded transaction:

\footnotetext{
172 Pahis, "Investment Misconceived", n. 45, fn. 99. On illegality of investments and abuse of rights, see J. E. Viñuales, "Defence Arguments in Investment Arbitration" (2020) 18 ICSID Rep 9, 30-4, $42-6$.

173 Regarding the distinction between jurisdiction and admissibility, J. Paulsson "Jurisdiction and Admissibility" in G. Asken and Others (eds.), Global Reflections on International Law, Commerce and Dispute Resolution: Liber Amicorum in Honour of Robert Briner (ICC Publishing, 2005), 601-17; A. Reinisch, "Jurisdiction and Admissibility in International Investment Law" (2017) 16 The Law \& Practice of International Courts and Tribunals 1, 21-43; Y. Shany, Questions of Jurisdiction and Admissibility before International Courts (Cambridge University Press, 2015); Waibel, "Jurisdiction and Admissibility", n. 103, 1261-1336.

174 Fakes v. Turkey, para. 112. 175 Phoenix Action v. Czech Republic, paras. 100-113.

176 Philip Morris Asia Limited v. Commonwealth of Australia, PCA Case No. 2012-12, Award on Jurisdiction and Admissibility (17 December 2015), paras. 535-84.

177 Mortenson, n. 2, $315 . \quad 178$ Ibid., 318.179 Ibid., 257.
} 
If a teenage backpacker slips and falls on public streets during a summer trip to New

Zealand, she should not be able to bring an ICSID claim based on her "investment" of time in the country. ${ }^{180}$

88. This illustration of a facially absurd investment is reminiscent of Douglas' example of a metro ticket seemingly qualifying as an investment. He contends that qualification of the ticket as an investment would do violence to the economic meaning of investment, even if such a ticket could be said to fulfil the legal elements for an investment. Douglas, in contrast to Mortenson, contends that:

"investment", however, is a term of art: its ordinary meaning cannot be extended to bring any rights having an economic value within its scope, for otherwise violence would be done to that ordinary meaning, in contradiction to Article 31 of the Vienna Convention on the Law of Treaties. The right to performance embodied in a metro ticket cannot qualify as an investment. ${ }^{181}$

89. Even investment treaties with broad, asset-backed definitions of investment for instance by including "claims to money", ${ }^{182}$ "obligations" or "any right of an economic nature granted by law or by contract"183 in their definition of investment - probably do not cover such "absurd" definitions of investment. Such absurd examples apart, under this approach, it is the investment treaty that is decisive. The reference in Article 25 ICSID Convention to "investment" does little, if any, work, rendering it superfluous.

90. Mortenson's analysis relies heavily on the common mischaracterisation of the statement in the Report of the Executive Directors 1965 that "[n]o attempt was made to define the term "investment". ${ }^{184}$ In contrast, as discussed above, there were multiple attempts to agree on a definition, but a consensus failed to emerge. According to Mortenson, the British proposal of including no definition of "investment", but providing for a mechanism of excluding certain disputes under Article 25(4) ICSID Convention, shows that the drafters opted for an extremely broad definition of investment ${ }^{185}$ that covers "any plausibly economic activity or asset". ${ }^{186}$ Consequently, applying the Salini criteria (or any other substantive elements) for the second leg of the test for investment is mistaken. Based on the drafting history, there is no need for the second leg of the test.

91. The Ambiente Ufficio tribunal adopted this approach. It cited Mortenson several times in support of its broad interpretation of the term "investment". In particular, the tribunal relied on Mortenson's reading of the 1965 Report of the Executive Directors on the ICSID Convention and the possibilities for States to

180 Ibid., 315.

181 Douglas, The International Law of Investment Claims, n. 141, para. 342 (emphasis added); cf. Romak v. Uzbekistan, para. 184 (declining to interpret "investment" purely based on the ordinary meaning because it would lead to a manifestly absurd or unreasonable result).

182 Deutsche Bank v. Sri Lanka, para. 284.

183 Ambiente Ufficio v. Argentina, paras. 488-95. The tribunal described the latter as a "catch-all clause". Ibid., para. 493.

184 Report of the Executive Directors 1965, n. 60, para. 9.

185 Mortenson, n. 2, 280-301; Schill, “Article 25”, n. 6, para. $163 . \quad{ }^{186}$ Mortenson, n. 2, 261. 
restrict the broad meaning of investment in Article 25 ICSID Convention through Article 25(4) notifications. ${ }^{187}$ The tribunal explained that

The very citation from the Report of Directors referred to above testifies to this tradeoff when it expressly links the lack of a definition of "investment", first, to the "essential requirement of consent by the parties" and, second, to the "mechanism" of Art. 25(4) of the Convention. However, the Report's wording is inaccurate inasmuch as the non-existence of a definition of "investment" in Art. 25(1) of the ICSID Convention was due to a deliberate abstention from including a definition rather than to a failure to agree on a definition. It is inaccurate inasmuch as the non-existence of a definition of "investment" in Art. 25(1) of the ICSID Convention was due to a deliberate abstention from including a definition rather than to a failure to agree on a definition. ${ }^{188}$

92. While not relevant to its decision, the tribunal did not adopt Mortenson's expansive view of investment under Article 25 ICSID Convention as regarding "any plausibly economic activity or asset". In obiter, the tribunal expressed a preference to exclude commercial transactions from the notion of investment (see paras. 97-103 below).

93. The mechanism in Article 25(4) ICSID Convention for excluding disputes does not mean that the notion of "investment" is "nonjusticiable" - that is, that the presence of this mechanism precludes ICSID tribunals from drawing "outer limits" of the term investment. ${ }^{189}$ Article 25(4) ICSID Convention speaks of disputes which can be excluded - not investments. ${ }^{190}$ The original, co-sponsored British proposal spoke of "investment disputes" for jurisdictional purposes (in what became Article 25(1) ICSID Convention) and of "class or classes of investment disputes" in relation to possible exclusions by notification (now Article 25(4) ICSID Convention). ${ }^{191}$ At the time of writing, only seven ICSID member States - all developing countries - had made such notifications. ${ }^{192}$ In some cases, States limited disputes to approved investments. ${ }^{193}$ Yet States also exclude sectors or they limit the applicability of treatment standards such as expropriation.

\footnotetext{
187 Ambiente Ufficio v. Argentina, paras. 441-74. 188 Ibid., para. 454.

189 But see Mortenson, n. 2, 299. Cf. also Fedax v. Venezuela, para. 33; Abaclat v. Argentina, para. 488.

190 Schill, "Article 25", n. 6, para. 281 ("State practice under Art. 25(4) of the Convention, which involves examples of Contracting Parties notifying the Centre of classes of disputes concerning specific economic activities they would not consider submitting to the jurisdiction of the Centre confirms this").

191 See para. 43 above.

192 The seven are China, Guatemala, Indonesia, Jamaica, Papua New Guinea, Saudi Arabia and Turkey. Three other States withdrew their notifications (Ecuador, Guyana and Israel). Ecuador withdrew from the ICSID Convention in December 2007. Cf. Hwang and Fong Lee Cheng, n. 9, 111-12 and fn. 64 (contending that Article 25(4) notifications are not the appropriate tool to limit broad BIT definitions of investment). Saudi Arabia's notification illustrates the potential breadth of such notifications under Article 25(4): "[T]he Kingdom reserves the right of not submitting all questions pertaining to oil and pertaining to acts of sovereignty to the International Centre for the Settlement of Investment Disputes whether by way of conciliation or arbitration": ICSID, "Contracting States and Measures Taken by Them for the Purpose of the Convention" (July 2020), 14 https://icsid.worldbank.org/sites/ default/files/2020_July_ICSID_8_ENG.pdf (accessed 11 December 2020).

193 For example, Mortenson, n. 2, 294.
} 
Put differently, this mechanism of exclusion under Article 25(4) ICSID Convention is not limited to transactions that do not qualify, in the view of the excluding State, as an investment.

94. The same reasoning applies to the two other methods which States could use to limit their exposure to investment arbitrations: (i) reservations to the ICSID Convention; ${ }^{194}$ and (ii) narrow definitions of "investment" in their investment treaties. ${ }^{195}$ Just because States can exclude certain disputes under Article 25(4) ICSID Convention, because they may enter a reservation, or because they may define investment in their investment treaties narrowly, does not imply that "investment" in Article 25 ICSID Convention needs to be interpreted narrowly or broadly. The possibility of excluding certain disputes does not substitute for State consent. ${ }^{196}$ This first approach renders "investment" in Article 25 ICSID Convention superfluous and deprives it of any real meaning - which is not in keeping with Article 31 VCLT. ${ }^{197}$

95. Moreover, just because the drafters failed to agree on a particular definition of investment and because they compromised by leaving the term undefined does not mean that "investment" has no ordinary meaning. The travaux préparatoires to the ICSID Convention show that there was no consensus regarding the definition of investment. By contrast, they do not demonstrate that the term "investment" has no ordinary meaning. The drafting technique of omitting a definition of "investment" delegates the task of identifying the ordinary meaning to interpreters and appliers of the ICSID Convention, such as States and ICSID tribunals. ${ }^{198}$ They are not free to come up with the meaning of "investment" $a b$ initio.

96. The argument that the drafters of the ICSID Convention rejected some objective characteristic, and that therefore ICSID tribunals cannot use it, fails to persuade. This argument would only apply if the drafters of the Convention agreed on alternative elements, or explicitly said that no elements applied. For example, that the drafters rejected a five-year minimum duration requirement ${ }^{199}$ does not mean that a tribunal is now not allowed to look at the duration of an alleged investment. In domestic law, just because a legislature fails to agree on the circumstances that render a shareholder a controlling shareholder - such as certain percentage of shares, certain voting rights, or a specific form of economic

\footnotetext{
194 The ICSID Convention does not expressly permit or prohibit reservations. That said, no State has made a reservation to the ICSID Convention. This is likely because Article 25(4) notification and the requirement of consent avoid the need for reservations: see "Article 68" in C. Schreuer, The ICSID Convention: A Commentary (Cambridge University Press, 2nd edn, 2009), paras. 3-5.

195 Mortenson, n. 2, 293-6. ${ }^{196}$ Report of the Executive Directors 1965, n. 60, para. 31.

197 C. Braumann and A. Reinisch, "Effet Utile" in J. Klingler, Y. Parkhomenko and C. Salonidis (eds.), Between the Lines of the Vienna Convention? Canons and Other Principles of Interpretation in Public International Law (Wolters Kluwer, 2019), 47. Mortenson, n. 2, 300 acknowledges that this approach renders the criterion of "investment" superfluous and that some basic limitation of economic development applies to the notion of investment.

198 Sattorova, n. 4 (rejecting the subjective approach and the Salini criteria, and advocating an approach based on the ordinary meaning that regards investment as a process rather than an asset); A. Roberts, "Power and Persuasion in Investment Treaty Interpretation: The Dual Role of States" (2010) 104 American Journal of International Law 179.

199 Mortenson, n. 2, 298.
} 
influence - does not mean that a court called upon to interpret the term "controlling shareholder" cannot consider those elements. What the rejection of specific elements during the drafting process does tell us is that the specifics of potential elements are not set in stone. Tribunals ought to apply them with some flexibility.

\section{The commercial transaction test: distinguishing investments from commercial transactions}

97. A third approach distinguishes between two mutually exclusive categories: commercial transactions and investments (the commercial transaction test). ${ }^{200}$ If the facts support the qualification of a transaction as "commercial", the transaction in question cannot at the same time be an investment. Vice versa, if a transaction is an investment, it follows that it cannot be a commercial transaction.

98. The distinction between commercial transactions and investments features prominently in the case law. ${ }^{201}$ For example, the tribunal in Ambiente Ufficio explained that:

there are good reasons to leave a single commercial transaction such as the delivery of a single load of cars outside the concept of investment and thus outside the subjectmatter jurisdiction of the Centre. ${ }^{202}$

99. The Ambiente Ufficio tribunal did not expand on what these "good reasons" were and referred to existing cases and the academic literature. It found that "sovereign bonds and security entitlements [are] in no way comparable to single commercial transactions". ${ }^{203}$ It also said in the instant case there was no need to decide whether any "plausibly economic activity or asset" qualified as an investment, referring to Mortenson's proposition that it did. ${ }^{204}$

100. By contrast, Pahis favours jettisoning the commercial transaction test that the Ambiente Ufficio tribunal, among other tribunals, used altogether because of the very expansive meaning of the term "investment" in Article 25 ICSID Convention, and conceptual flaws and practical difficulties associated with this test. ${ }^{205} \mathrm{He}$ argues that basic economic definitions of "investment" cover a sale of goods (or any economic transaction that produces value in the future). ${ }^{206}$ Yet under Article 31 VCLT, the ordinary meaning of the term "investment" needs to be interpreted in the context and in the light of the object and purpose of the ICSID Convention.

\footnotetext{
200 Hwang and Fong Lee Cheng, n. 9; Pahis, "Investment Misconceived", n. 45, 85-93.

201 For a discussion of eight cases (Joy Mining v. Egypt, Malaysian Historical Salvors v. Malaysia, Romak v. Uzbekistan, Global Trading Resource v. Ukraine, Alps Finance v. Slovak Republic, Nova Scotia Power v. Venezuela, Poštová banka v. Greece and Tenaris SA and Talta - Trading e Marketing Sociedade Unipessoal Lda v. Bolivarian Republic of Venezuela, ICSID Case No. ARB/11/26, Award (29 January 2016) [Tenaris v. Venezuela]) see Pahis, "Investment Misconceived", n. 45, 85-93.

202 Ambiente Ufficio v. Argentina, para. 470; Cf. also Malaysian Historical Salvors v. Malaysia Annulment Dissent, para. 21 (citing Schreuer).

203 Ambiente Ufficio v. Argentina, para. 470. 204 Ibid.

205 Pahis, "Investment Misconceived", n. 45. 206 Ibid., 105.
} 
101. Pahis distinguishes between negative and positive definitions of "investment". ${ }^{207}$ The positive Salini criteria, on their own, have little bite, but the commercial transaction test does. However, he acknowledges that the negative commercial transaction test "ascribes certain positive attributes to investments - based on but distinct from the Salini criteria - in order to distinguish investments from commercial activities". ${ }^{208}$ But by construing the Salini criteria so broadly, there is little difference with the new objectivism described above. As Pahis acknowledges, "[i]f all or nearly all claims pass the Salini test, there is little practical difference between the Salini test and a subjective interpretation of Article 25 'investment". 209

102. A further reason for abandoning the commercial transaction test is that investment tribunals rarely apply the "commercial transaction test" without also applying the Salini criteria. The commercial transactions test adds bite to the Salini test. ${ }^{210}$ In six out of the eight awards that Pahis examines, tribunals apply both tests together to distinguish between commercial transactions and investment. ${ }^{211}$ Among the two remaining ones, the tribunal in Global Trading Resource v. Ukraine applied only the commercial transactions test. But this was only because the tribunal decided that the claims were manifestly without legal merit due to the putative investment being a commercial transaction. As a result, the tribunal did not need to analyse the elements for investment in detail. ${ }^{212}$ The second case, Tenaris v. Venezuela, is ambiguous. The tribunal held:

The Tribunal accepts Venezuela's submission [referring to Venezuela's Post-Hearing Brief] that the Off-Take Agreement is not an "investment" in its own right. Nor does it consider that the Off-Take Agreement would constitute an investment, if an holistic approach were adopted: despite the context in which it was concluded, it remains, in essence, a commercial agreement in respect of the purchase and delivery of product at a known price, and in such a manner that Talta took off-shore Venezuela the benefit of the profit of the on-sale in the open market. To this end, the Tribunal considers that the Off-Take Agreement must be treated differently to the Talta Loan. ${ }^{213}$

103. The specific arguments that the tribunal accepted remain unknown. Venezuela argued against the qualification as investment based particularly on the elements of contribution and risk. Among others, it invoked Romak. ${ }^{214}$

\section{E. Elements of investments in ICSID Additional Facility, UNCITRAL or SCC cases}

104. Two reported awards of tribunals operating under non-ICSID arbitration rules found that "investment" has the same meaning in non-ICSID investment

\footnotetext{
207 Ibid., 99-117. 208 Ibid., 73 (emphasis added).

209 Ibid., 98. For a discussion of the cases, see Section III.B above on the Salini criteria. $\quad{ }^{210}$ Ibid.

211 Joy Mining v. Egypt, Malaysian Historical Salvors v. Malaysia, Romak v. Uzbekistan, Alps Finance v. Slovak Republic, Nova Scotia Power v. Venezuela, Poštová banka v. Greece. The two remaining ones are Global Trading Resource v. Ukraine and Tenaris v. Venezuela. See Pahis, "Investment Misconceived", n. 45, 94-5.

212 Global Trading Resource v. Ukraine, paras. 54-8.

213 Tenaris v. Venezuela, para. 291; see Romak v. Uzbekistan, paras. 64-5.

214 Tenaris v. Venezuela, paras. 255-61.
} 
arbitrations, even though Article 25 ICSID Convention does not apply in these arbitrations. In MNSS v. Montenegro, in a dispute concerning shares and loans in an electric arc furnace steel mill, the tribunal held that an investment under Article 2(a) ICSID Additional Facility Rules ${ }^{215}$ needed to be an investment under the ICSID Convention. ${ }^{216}$ The tribunal based this reasoning on Article 4(2) ICSID Additional Facility Rules, ${ }^{217}$ without providing further reasons. The tribunal considered that the term "investment" was identical under both the ICSID Convention and the ICSID Additional Facility. The ICSID Additional Facility applied when ICSID tribunals lacked jurisdiction under the ICSID Convention because of the absence of consent. Such consent was missing if "either the State party to the dispute or the State whose national is a party to the dispute is not a Contracting State", rather than because there was no "investment" under Article 25 ICSID Convention. Article 2(b) covers legal disputes that do not "arise directly out of an investment". 218

105. In Romak, the Switzerland-Uzbekistan BIT offered the investor a choice between arbitration under UNCITRAL Rules and under the ICSID Convention. ${ }^{219}$ The tribunal was constituted under the UNCITRAL Rules. The investor argued that only the BIT was relevant for interpreting the term "investment" and urged the tribunal not to adopt the double-barrelled test. The tribunal disagreed and held that the term "investment" is the same irrespective of whether the tribunal is constituted under UNCITRAL Rules or the ICSID Convention. ${ }^{220}$ This is because "investment" has an inherent meaning under investment treaties, and applied three Salini criteria under the BIT. Otherwise the distinction between investments and purely

215 ICSID Additional Facility Rules, Art. 2(a): "The Secretariat of the Centre is hereby authorized to administer, subject to and in accordance with these Rules, proceedings between a State (or a constituent subdivision or agency of a State) and a national of another State, falling within the following categories: (a) conciliation and arbitration proceedings for the settlement of legal disputes arising directly out of an investment which are not within the jurisdiction of the Centre because either the State party to the dispute or the State whose national is a party to the dispute is not a Contracting State ..."

216 MNSS v. Montenegro, paras. 184-6. However, the two other ICSID Additional Facility cases under NAFTA Chapter 11 reported in this volume (Apotex and Bayview) remain silent on whether the same notion of investment as under Article 25 ICSID Convention applied in ICSID Additional Facility cases.

217 ICSID Additional Facility, Art. 4(2): "In the case of an application based on Article 2(a), the Secretary-General shall give his approval only if (a) he is satisfied that the requirements of that provision are fulfilled at the time, and (b) both parties give their consent to the jurisdiction of the Centre under Article 25 of the Convention (in lieu of the Additional Facility) in the event that the jurisdictional requirements ratione personae of that Article shall have been met at the time when proceedings are instituted."

218 ICSID Additional Facility Rules, Art. 2(b): "The Secretariat of the Centre is hereby authorized to administer, subject to and in accordance with these Rules, proceedings between a State (or a constituent subdivision or agency of a State) and a national of another State, falling within the following categories: ... (b) conciliation and arbitration proceedings for the settlement of legal disputes which are not within the jurisdiction of the Centre because they do not arise directly out of an investment, provided that either the State party to the dispute or the State whose national is a party to the dispute is a Contracting State." Cf. also Schill, "Article 25", n. 6, paras. 485-6.

219 Agreement between the Swiss Confederation and the Republic of Uzbekistan on the Promotion and Reciprocal Protection of Investments (adopted 16 April 1993, entered into force 5 November 1993) SR 0.975.262.1, Art. 9(2), (3). Switzerland and Uzbekistan were both members of the ICSID Convention when the investor submitted the request for arbitration, Romak v. Uzbekistan, para. 193, fn. 161.

220 Romak v. Uzbekistan, paras. 193-6. 
commercial transactions (see above) would become nugatory. ${ }^{221}$ It justified that conclusion with effet utile and policy considerations, such as that otherwise significant and undesirable differences between ICSID and UNCITRAL arbitrations would

lead to "unreasonable" results. This view would imply that the substantive protection offered by the BIT would be narrowed or widened, as the case may be, merely by virtue of a choice between the various dispute resolution mechanisms sponsored by the Treaty. This would be both absurd and unreasonable. Naturally, there are specific jurisdictional restrictions imposed by the ICSID Convention (for example, the limitation with respect to physical persons who are dual nationals, or to the existence of a "legal dispute"). However, said restrictions do not bear on the definition of "investment". There is no dispute that the ICSID Convention's drafters offered no definition for the term "investment." There is no basis to suppose that this word had a different meaning in the context of the ICSID Convention than it bears in relation to the BIT. Indeed, the drafters appear to have excluded any specific definition from the ICSID Convention precisely to accord contracting parties a great deal of flexibility in their designation of transactions or disputes as investment-related in their instruments of consent.

On this basis, it would be unreasonable to conclude that the Contracting Parties contemplated a definition of the term "investments" which would effectively exclude recourse to the ICSID Convention and therefore render meaningless - or without effet utile - the provision granting the investor a choice between ICSID or UNCITRAL Arbitration. As already noted, this would run counter to the rule of construction requiring the interpreter to infer that a State party to two or more treaties which employ the same term in the same (or a similar) context intended to give said term the same (or at least a compatible) meaning in all the treaties. ${ }^{222}$

106. Notwithstanding, Article 2(b) ICSID Additional Facility Rules (which allows for ICSID conciliation/arbitration proceedings despite the lack of an investment under Article 25 ICSID Convention) requires that the underlying transaction displays "features which distinguish it from an ordinary commercial transaction". 223

107. In contrast to MNSS and Romak, the Enkev Beheer v. Poland tribunal, in proceedings governed by the UNCITRAL Arbitration Rules, did not discuss whether any elements of an investment were required, and did not opine on whether the definition of investment in UNCITRAL arbitration was the same as in ICSID arbitration. ${ }^{224}$ Presumably, there was no discussion because a $79 \%$ share ownership in a Polish company qualifies as an investment even under the most stringent Salini criteria. The investor's argument that (i) the allocation of profits by the Polish company, (ii) the goodwill and know-how created by it, and (iii) the time and management effort by the investor, each qualified independently as

221 Ibid., para. 185. ${ }^{222}$ Ibid., paras. 194-5.

223 ICSID Additional Facility Rules, Art. 4(3); cf. Schill, "Article 25”, n. 6, para. 486. On ordinary commercial transactions, see further Section III.D above.

224 Enkev Beheer v. Poland. 
investments failed because the tribunal regarded them as rights "derived from shares" rather than independent investments. The investor lacked standing to claim for harm suffered by the Polish company. ${ }^{22}$

108. Similarly, in the SCC arbitration Quasar de Valors v. Russia, the tribunal limited itself to discussing the investment treaty's definition of investment in arbitration concerning a type of financial instrument, namely American Depository Receipts traded on the New York stock exchange in Russian company Yukos. ${ }^{226}$ Unlike in Enkev, the transaction in this arbitration was not straightforwardly an investment. The absence of a discussion in the award of Salini or other objective elements of investment appears to indicate that the tribunal did not consider that any such criteria applied in an SCC arbitration.

109. In sum, of the 21 reported decisions in this volume, 11 adopt at least some of the Salini criteria. In this group of cases, most tribunals concentrated on three elements of an investment: contribution, duration and risk. Contribution as an element of investment features in 11 cases; duration in eight cases; and risk in 10 (see Table 2). ${ }^{227}$ The three elements of economic development, profit and return, and territoriality play only a minor role. There is little agreement among tribunals on how to assess the presence of an investment.

\section{SPECIAL AND CONTROVERSIAL CASES OF INVESTMENTS}

110. This final section considers two special cases: (i) financial instruments as investments; (ii) commercial arbitration awards, investment arbitration awards and judgments of national courts as investments. With respect to both categories, based on the existing case law there is uncertainty about whether and the extent to which they can be considered investments, particularly because of an undercurrent of strong dissent. One source of this uncertainty is whether either financial instruments or awards/judgments can qualify as investments on their own, or only if they are associated with an underlying investment.

\section{A. Financial instruments: lack of legal certainty}

111. The question whether portfolio investment in general, and financial instruments in particular, count as investment for purposes of Article 25 ICSID

\footnotetext{
225 Ibid., paras. 310-13.

226 Quasar de Valors v. Russia, paras. 135-47. Cf. Yukos Universal Limited (Isle of Man) v. Russian Federation, PCA Case No. AA 227, Final Award (18 July 2014).

227 Cf. Douglas, The International Law of Investment Claims, n. 141, 189ff (mentions contribution, risk and profit/return); Hwang and Fong Lee Cheng, n. 9, 104; E. Gaillard and Y. Banifatemi, “'Biwater,' Classic Investment Bases: Input, Risk, Duration” (2008) 240(126) New York Law Journal; Reinisch, "Jurisdiction and Admissibility", n. 173, 28 (the three elements comprising "a re-interpreted Salini-light-test").
} 
Convention and under investment treaties remains contentious. ${ }^{228}$ The sovereign debt crises in Argentina (2001) and Greece (2012) led to four known investment arbitrations related to sovereign debt. In three of those four disputes, ICSID tribunals upheld their jurisdiction over sovereign bonds. ${ }^{229}$ However, in Poštová banka v. Greece, another ICSID tribunal declined jurisdiction. ${ }^{230}$ In addition to sovereign bonds, investment tribunals have qualified other financial instruments, such as promissory notes, American Depository Receipts and hedging agreements, as investments. ${ }^{231}$ In future, investors may also argue that sovereign insurance, crypto financial instruments or central bank issued digital currencies count as investments. ${ }^{232}$

112. Financial instruments are not foreign direct investment but portfolio investment. Many investment treaties expressly include certain forms of portfolio investments in their investment definitions. With respect to sovereign bonds and loans specifically, States opted for different strategies on the inclusion of bonds and loans in their bilateral investment treaties. Compare the positions of the UK and Germany in their early investment treaties in the 1960s and 1970s. The UK took the view that financial instruments were included in the definition of investment in British investment treaties, even though they did not say so explicitly, and resisted attempts by counterparties to exclude them. ${ }^{233}$ By contrast, Germany seemingly differentiated between foreign direct investment (covered) and financial or portfolio investment (excluded). ${ }^{234}$

113. In the disputes concerning financial instruments to date, two Salini criteria risk and contribution - have been significant battle grounds (see the discussion

228 M. Sornarajah, The International Law on Foreign Investment (Cambridge University Press, 3rd edn, 2010), 314 ("The travaux préparatoires of the ICSID Convention show that the overwhelming concern was with foreign direct investment."); S. P. Subedi, International Investment Law: Reconciling Policy and Principle (Hart, 2008), 48, 62 ("opinions are divided on the inclusion of portfolio investment in the definition of investment"); D. Krishnan, "A Notion of ICSID Investment" in T. J. Grierson Weiler (ed.), Investment Treaty Arbitration and International Law (Jurisnet, 2008); M. Dekastros, "Portfolio Investment: Reconceptualising the Notion of Investment under the ICSID Convention" (2013) 14 Journal of World Investment and Trade 286 (portfolio investment included in the notion of investment); Bonnitcha, Poulsen and Waibel, n. 54, 33 ("investment treaties cover many types of portfolio investment as well").

229 Abaclat v. Argentina; Ambiento Ufficio v. Argentina; Giovanni Alemanni and Others v. Argentine Republic, ICSID Case No. ARB/07/8, Decision on Jurisdiction and Admissibility (17 November 2014). See further S. Pahis, "BITs and Bonds: The International Law and Economics of Sovereign Debt" (2021) 115 American Journal of International Law 242, 244.

230 The request for annulment was unsuccessful. The annulment committee considered that "the Tribunal provided a detailed description of the characteristics of sovereign debt and securities, which, in its view, place[d] Poštová's GGB [Greek Government Bonds] interests outside the definition of investment"; K. Nakajima, "Parallel Universes of Investment Protection? A Divergent Finding on the Definition of Investment in the Arbitration on Greek Sovereign Debts" (2016) 15 The Law \& Practice of International Courts and Tribunals 472 (considering terminological differences between this arbitration and the three Argentine bond cases).

231 E.g. Fedax v. Venezuela (promissory notes); Československá Obchodní Banka AS v. Slovak Republic, ICSID Case No. ARB/97/4, Decision on Objections to Jurisdiction (24 May 1999) [CSOB v. Slovakia] (loans); Abaclat v. Argentina (sovereign debt/security entitlements); Quasar de Valors v. Russia (American Depository Receipts); Deutsche Bank v. Sri Lanka (oil hedging).

${ }_{232}$ European Central Bank, Report on a Digital Euro (October 2020) www.ecb.europa.eu/pub/pdf/ other/Report_on_a_digital_euro 4d7268b458.en.pdf (accessed 20 December 2020).

233 Hepburn, Paparinskis, Poulsen and Waibel, n. 72, $939 . \quad{ }^{234}$ Ibid. 
above). ${ }^{235}$ The main issue is whether financial instruments involve more than ordinary commercial risk, which some tribunals require to have jurisdiction. With respect to contribution, the main issues are whether financial instruments which are not typically governed by the law of the host country or subject to the jurisdiction of its courts - "contribute" to the host State (occasionally, tribunals link this element to whether there is an investment "in the territory" of the host country).

114. In Ambiente Ufficio, the tribunal found that the "broad" meaning of "investment" in Article 25 ICSID Convention covered bonds and security entitlements. ${ }^{236}$ Departing from the three Argentine bond cases, the tribunal in Poštová banka held that a bond needs to be distinguished from a loan. While the applicable BIT covered a loan, the same did not apply to a bond, because a bond - in contrast to a loan - was tradable. ${ }^{237}$ In obiter dicta, the tribunal stated on Article 25 ICSID Convention:

If an "objective" test is applied, in the absence of a contribution to an economic venture, there could be no investment. An investment, in the economic sense, is linked with a process of creation of value, which distinguishes it clearly from a sale, which is a process of exchange of values or a subscription to sovereign bonds which is also a process of exchange of values i.e. a process of providing money for a given amount of money in return ... the contribution, as an element of investment, has to be involved in an economic operation creating value.$^{238}$

115. Moreover, investment tribunals are split on whether there is a distinction between bonds (loans) that are associated with an investment because they fund an investment, and free-standing loans or bonds. ${ }^{239}$ In addition to the three Argentine sovereign bonds cases, ${ }^{240}$ the tribunal in Deutsche Bank v. Sri Lanka found that a free-standing oil hedging agreement between a European bank and a State-owned company in Sri Lanka amounted to an investment.

\footnotetext{
235 The tribunals in the two early cases on debt instruments - Fedax v. Venezuela (promissory notes) and $C S O B$ v. Slovakia (loans) - accepted jurisdiction. For a critical discussion, see Waibel, "Opening Pandora's Box", n. 2, 720-2.

236 Ambiente Ufficio v. Argentina, paras. 470-4. For a discussion of the issue of mass claims, see S. I. Strong, M. Waibel and S. Wordsworth, "Investment Arbitration: Mass Claims" (2014) 8 World Arbitration and Mediation Review 3.

237 Poštová banka v. Greece, paras. 336-40. The applicable BIT did not expressly include bonds, unlike the Argentina-Italy BIT that provided the basis for the three Argentine bond cases.

238 Poštová banka v. Greece, para. 361.

239 E. Gaillard, La Jurisprudence du CIRDI (Pedone, 2004), 479 ("un simple prêt dont la remuneration ne depend en rien du succès de l'enterprise ne peut être qualifié d'investissement"; author's translation: "a simple loan whose return does not depend on the success of an enterprise cannot be qualified as an investment"); Phoenix Action v. Czech Republic, para. 114; Waibel, "Opening Pandora's Box”, n. 2, 728 (favouring requiring the "association with a commercial undertaking" as a typical element of an "investment" in Article 25 ICSID Convention). Support for the view that project financing under the Energy Charter Treaty amounted to an investment, and that the lender could bring its own claim, not just the direct or indirect owner of the investment, is found in Portigon AG v. Kingdom of Spain, ICSID Case No. ARB/17/15, Decision on Jurisdiction (20 August 2020) [Portigon v. Spain].

240 Abaclat v. Argentina, para. 375; Ambiente Ufficio v. Argentina, para. 503 (rejecting that the funds in question need to be traceable to a "specific project, enterprise or activity in the host State's territory").
} 
116. In Portigon v. Spain, the majority of the tribunal considered that financial instruments (loans and hedging instruments) related to the financing of Spanish renewable projects were investments under the ICSID Convention and the ECT. ${ }^{241}$ The tribunal recognised this distinction between free-standing loans and those associated with an investment. The tribunal did not rule on whether free-standing loans could amount to an investment. The MNSS tribunal stated that a loan itself did not qualify as an investment, but did so if connected to an economic operation. $^{242}$ Similarly, the tribunal in Global Trading Resource v. Ukraine decided that a claim to money needed to be associated with an investment with respect to the specific definition of a "claim to money" in the Ukraine-US BIT. ${ }^{243}$ The delivery of poultry, despite the outlay of money, was not an investment under Article 25(1) ICSID Convention. The outlay of money was a common feature of supply contracts. ${ }^{244}$

117. The tribunals in Romak and Poštová banka also differentiated between investment risk and commercial risk (see Section III.B.iii above). If one applies the reasoning of Romak and Poštová banka, an oil hedging agreement on closer inspection only displays the risk of an ordinary commercial transaction (market price and contractual non-performance), rather than an investment risk. There is a known method for calculating the profitability of the transaction, even if, of course, the amount itself is unknown when the agreement is concluded. Compare this to the sale and delivery of oil, which most tribunals do not qualify as an investment. Yet the tribunal in Deutsche Bank v. Sri Lanka decided otherwise.

118. An oil hedging agreement provides insurance to the insuree against the price of oil rising. Based on the ratio of the Deutsche Bank tribunal, flood insurance provided by an insurance company such as AIG or Allianz to a country would also qualify as an investment. The risk of non-performance or default is not a useful standard to qualify transactions as investments. ${ }^{245}$ The implication is that almost all transactions amount to investments. ${ }^{246}$

\footnotetext{
241 Portigon v. Spain. The decision and dissenting opinion are not yet publicly available. See L. Bohmer, "Breaking: Majority arbitrators uphold jurisdiction over claims by financial institution which funded renewable energy projects in Spain" Investment Arbitration Reporter (21 August 2020) www-iareportercom.uaccess.univie.ac.at/articles/breaking-majority-arbitrators-uphold-jurisdiction-over-claims-by-financial-institution-which-funded-renewable-energy-projects-in-spain (accessed 26 August 2020).

242 MNSS v. Montenegro, para. 196.

243 Global Trading Resource v. Ukraine, paras. 47-51 ("as subparagraph (a)(iii) says in plain words"). Cf. Treaty between the United States of America and Ukraine Concerning the Encouragement and Reciprocal Protection of Investments (adopted 4 March 1994, entered into force 16 November 1996) TIAS 96-1116, Art. I(1)(a)(iii): "a claim to money or a claim to performance having economic value, and associated with an investment".

244 Global Trading Resource v. Ukraine, paras. 55-6.

245 Waibel, "Opening Pandora's Box", n. 2, 726. See also the discussion of the ordinary commercial transactions test in Section III.D above.

246 Deutsche Bank v. Sri Lanka Dissent, paras. 62-74 (under the majority's approach "[a]lmost every agreement would $\ldots$ be presumed to be an investment").
} 
119. Among other reasons, dissenting arbitrator Torres Bernárdez in Ambiente Ufficio v. Argentina stated that the sale had been a commercial transaction and pointed to the lack of a "host State" for the sovereign bonds:

Neither the Argentine Republic acted as the host State of an investment when selling the sovereign bonds nor, for the matter, the placement banks (underwriters) were acting as foreign private investors in the territory of Argentin[a] when purchasing the sovereign bonds in the primary market.

The Republic of Argentina was "hosting" nothing as a result of the transactions considered, but making a commercial dealing of a financial product of its own outside the Republic in international markets as could be the selling of any other eventual kind of Argentine governmental goods, getting a price in return. Then, the security entitlements holding by the Claimants cannot have acquired as concluded by the majority a non-existent "investment" quality of those sovereign bonds, because no one could transfer a better title than what he really has (nemo dat quod non habet) $\ldots{ }^{247}$

120. Differences among tribunals as to whether to qualify financial instruments as investments, and the unresolved issues set out below, have generated uncertainty for investors and host States. ${ }^{248}$ The absence of a jurisprudence constante ${ }^{249}$ leaves considerable room for manoeuvre to an investment tribunal called upon to decide disputes arising out of financial instruments.

\section{B. Arbitral awards and judgments as investments}

\section{i. Commercial arbitral awards}

121. While the issue of commercial arbitral awards as investments remains disputed, commercial arbitral awards themselves are not investments. However, provided the underlying transaction, viewed in its entirety, qualifies as an investment, the award can be seen as arising directly out of the same investment. ${ }^{250}$ For example, the Saipem v. Bangladesh tribunal, the first to consider this issue, looked

\footnotetext{
247 Ambiente Ufficio v. Argentina, Dissenting Opinion of Santiago Torres Bernárdez, paras. 187-8.

248 Cf. Douglas, The International Law of Investment Claims, n. 141, para. 401 (criticising the uncertainty resulting from the ill-defined notion of investment in general, "the concept of an investment cannot be one in search of meaning in the pleadings submitted to an investment treaty tribunal"); $A E S$ v. Kazakhstan, paras. 204-6 (list of exceptions in the domestic investment statute was exhaustive given the need for predictability); Pahis, "Investment Misconceived", n. 45, 71 (uncertainty creates significant waste). With respect to sovereign bonds specifically, Pahis, "BITs and Bonds", n. 229, 252 considers that "jurisdictional uncertainty ... now appears to have been resolved largely in favor of creditors ... the weight of arbitral precedent has concluded that sovereign bonds are in fact protected "investments.", 249 E. Gaillard and Y. Banifatemi, "The Long March towards a Jurisprudence Constante on the Notion of Investment: Salini v. Morocco, ICSID Case No. ARB/00/4" in M. Kinnear and Others (eds.), Building International Investment Law: The First 50 Years of the ICSID Convention (Kluwer Law International, 2015), 97-125.

250 Schill, “Article 25", n. 6, paras. 303-5; Saipem SpA v. People's Republic of Bangladesh, ICSID Case No. ARB/05/7, Decision on Jurisdiction and Recommendation on Provisional Measures, (21 March 2007) [Saipem v. Bangladesh], paras. 113, 127 (noting that "the contract rights which are crystallized by the Award constitute an investment within Article 1(1)(c) of the BIT"); ATA v. Jordan, paras. 113ff; White Industries Australia Limited v. Republic of India, UNCITRAL, Award (30 November 2011), paras. 7.8.8-10.
} 
to the "entire operation", and considered that the arbitral award arose directly out of the overall investment. ${ }^{251}$ At the same time, the tribunal was "not prepared to accept" that a commercial arbitration award by an ICC arbitral tribunal seated in Dhaka in relation to a gas pipeline construction contract itself amounted to an investment. ${ }^{252}$ It also indicated that the "rights arising out of the ICC Award arise only indirectly from the investment". 253

122. The Gavazzi tribunal found that an award that compensated for an investment in the host country's territory was protected as investment under Article 25 ICSID Convention, as well as the BIT. The Claimants did not submit that the award was a distinct investment from their acquisition of shares in a steel company as part of Romania's privatisation during the 1990s. Regarding Article 25 ICSID Convention, the tribunal held that the award "forms part of the Claimants' overall investment". ${ }^{254}$ Regarding the BIT, it accepted that the award, as a claim of money, qualified as a distinct investment, leaving the door open to commercial arbitration awards qualifying as an investment on their own:

The Arbitral Tribunal (by a majority) accepts the Claimants' case that an award which compensates for an investment made in the host State is a claim to money covered by the BIT as an investment. It also accepts, as regards Article 25 of the ICSID Convention, that, in the particular circumstances of this case, the 2007 Romanian Award forms part of the Claimants' overall investment. ${ }^{255}$

123. By contrast, the GEA v. Ukraine tribunal considered that an ICC award was only "a legal instrument, which provides for the disposition of rights and obligations", and not itself an investment. ${ }^{256}$ It explained that the award and the underlying investment - certain contractual and property rights under a contract were distinct:

the fact that the Award rules upon rights and obligations arising out of an investment does not equate the Award with the investment itself. In the Tribunal's view, the two remain analytically distinct, and the Award itself involves no contribution to, or relevant economic activity within, Ukraine such as to fall - itself - within the scope of Article 1(1) of the BIT or (if needed) Article 25 of the ICSID Convention. ${ }^{257}$

124. In Romak, the tribunal did not rule on whether a commercial award could qualify as investment in the abstract, as this depended on the facts of the case. A contract for the supply of 50,000 tons of wheat did not qualify as an investment. The tribunal held the same conclusion applied to the commercial arbitral award under the auspices of the Grain and Feed Trade Association because it and the purported investment were

\footnotetext{
251 Schreuer, "The unity of an investment", n. 124, 5. Schreuer was one of the arbitrators in Saipem v. Bangladesh.

252 Saipem v. Bangladesh, para. 113. ${ }^{253}$ Ibid. (emphasis in original).

254 Gavazzi v. Romania, para. 120. 255 Ibid. (emphasis added).

256 GEA Group Aktiengesellschaft v. Ukraine, ICSID Case No. ARB/08/16, Award (31 March 2011), para. 161 .

257 Ibid., para. 162.
} 
so inextricably linked ... that any determination as to whether [Claimant] holds and [sic] investment under the BIT cannot be made without reference to the entire economic transaction that is the subject of these arbitral proceedings ... If the underlying transaction is not an investment within the meaning of the BIT, the mere embodiment or crystallization of rights arising thereunder in an arbitral award cannot transform it into an investment. ${ }^{258}$

125. The tribunal's approach suggests that commercial arbitration awards can only qualify as an investment if they "arise directly out of an investment", rather than on their own. Some recent investment treaties - such as CETA and the EUVietnam FTA - expressly confirm that arbitral awards involving claims to money related to the delivery of goods or services do not qualify as investments. ${ }^{259}$ E contrario, arbitral awards that relate to an underlying transaction that amounts to an investment could be considered to be part of that investment.

\section{ii. Investment arbitral awards}

126. So far, investment tribunals have only decided that the transaction underlying commercial arbitral awards rather than investment awards can qualify as investments. ${ }^{260}$ Do investment arbitral awards qualify as investments in their own right or, alternatively, as "directly arising" out of the underlying investment? First, it is difficult to imagine that investment awards by denationalised arbitral tribunals or tribunals with a seat outside the host country could independently qualify as an investment in the host State. ${ }^{261}$ It is only if investment tribunals dispensed with the element of territoriality that they could conclude that an investment award on its own amounts to an investment. ${ }^{262}$

127. By contrast, investment arbitral awards, like commercial arbitral awards, could form part of an investment overall. Every investment award in favour of an investor, by definition, has its origins in an investment (otherwise the investment tribunal would have lacked jurisdiction). ${ }^{263}$ This conclusion applies even if the investment award is not considered to "arise directly out of an investment". A legal dispute concerning an investment award arguably does not "arise directly out of an investment", because the dispute is at one remove from the investment, mediated by the investment award.

iii. Judgments of national courts in the host country

128. Similar reasoning to the one that tribunals have developed for commercial arbitration awards (and possibly for investment arbitral awards in the future) could

258 Romak v. Uzbekistan, para. 211. 259 See Section II.A above. $\quad{ }^{260}$ Ibid.

261 For a definition of "award", see L. A. Mistelis, "Award as an Investment: The Value of an Arbitral Award or the Cost of Non-Enforcement" (2013) 28 ICSID Review - Foreign Investment Law Journal 64.

262 However, as shown above in Section III.B.vi, most investment tribunals do not insist on territory as an element of the notion of investment in Article 25 ICSID Convention.

263 Tribunals differ on whether claims relating to investments are assignable pre- and post-award: see N. Goh. "The Assignment of Investment Treaty Claims: Mapping the Principles" (2019) 10 Journal of International Dispute Settlement 23; and K. Claussen, "The International Claims Trade" (2020) 41 Cardozo Law Review 1743. 
also apply to judgments of national courts in the host country. Such judgments could be considered part of an overall investment, and as such they could benefit from the protection of the applicable investment treaty. The territorial element of a national judgment is more pronounced than for investment arbitral awards that typically lack any link to the host country's territory. This conclusion is supported by language in some recent investment treaties that confirm that judgments involving claims to money related to the delivery of goods or services do not qualify as investments. ${ }^{264}$ E contrario, national judgments that relate to an underlying transaction that qualifies as an investment could be considered to be part of that investment.

\section{CONCLUSION}

129. The analysis in this study shows that the notion of investment - which is the cornerstone of the subject matter jurisdiction of (ICSID) investment tribunals remains in flux. Investment tribunals have used a range of elements to assess whether transactions amount to investments under Article 25 ICSID Convention. The most common elements are contribution, duration and risk, though the cases at times display considerable variation in how they define and apply these elements and add additional elements to the mix. A minority of investment tribunals chooses a subjective approach and looks exclusively to the investment treaty as the instrument of consent to determine which transactions count as investments.

130. Over time, investment tribunals have refined the elements of investment. Nevertheless, a consensus among tribunals remains elusive. This study summarised the main approaches adopted in the decisions reported, with a view to providing a roadmap for future investment tribunals called upon to determine whether transactions that straddle the outer bounds of the notion of investment fall within the ambit of their jurisdiction or not. By providing an analytical overview, including through Tables $1-3$, of the existing cases and comparing and contrasting the varied approaches of investment, the study hopes to contribute to greater clarity on a question that has been, and continues to be, one of the most contested in international investment law. ${ }^{265}$ In part, this is due to an undercurrent of dissent, particularly in investment disputes related to financial instruments, by arbitrators Abi-Saab in Abaclat, Khan in Deutsche Bank and Torres Bernárdez in Ambiente Ufficio.

131. Because the notion of investment is crucial to the coverage of investment treaties, it is decisive for whether investment treaties deliver on their objectives such as promoting cross-border investment with the aspiration of furthering the host country's economic development. For instance, if there is a lack of clarity

\footnotetext{
264 See Section II.A above.

265 B. Moselle, "Economics and Meaning of 'Investment", in Y. Banifatemi (ed.), Jurisdiction in Investment Treaty Arbitration (JurisNet, 2018).
} 
ex ante on the threshold matter of whether Article 25 of the ICSID Convention/the applicable investment treaty covers portfolio investment or financial instruments, the parties to such transactions cannot rely on the investment treaty ex ante and their behaviour is unaffected by the treaty. The investor may claim ex post that the treaty applies, but without the ex ante certainty that the treaty applies ex post.

132. For the same reason, a principled and consistent approach to subject matter jurisdiction is also important from an ex post perspective. Because the notion of investment concerns a preliminary issue in investor-State arbitration, legal certainty on what transactions amount to investments - the enemy of which are conflicting awards ${ }^{266}$ - is also important from a cost perspective. The more arguments investors and host States alike present on subject matter jurisdiction, the more tribunal time is taken up with this jurisdictional matter, the higher the costs of the arbitration and especially costs of legal representation on average something that is not in the interest of either type of party ex ante (even if ex post it is often rational for the parties to incur large costs to obtain a jurisdictional ruling in their favour). Based on this, a principled understanding of what counts as an investment across investment treaties is important.

\title{
Appendix
}

\section{List of cases covered in this study}

\begin{abstract}
NB: cases in the ICSID Reports are in bold type and those reported in this volume are marked with (*)
\end{abstract}

\section{INTERNATIONAL COURT OF JUSTICE}

Dispute regarding Navigational and Related Rights (Costa Rica v. Nicaragua) Judgment, ICJ Reports 2009, p. 213

Whaling in the Antarctic (Australia v. Japan: New Zealand intervening) Judgment, ICJ Reports 2014, p. 226

\section{INVESTMENT ARBITRATION AWARDS}

Abaclat and Others (Case Formerly Known as Giovanna a Beccara and Others) v. Argentine Republic, ICSID Case No. ARB/07/5, Decision on Jurisdiction and Admissibility (4 August 2011) (*)

266 W. M. Reisman and A. Vinnik, "What Constitutes an Investment and Who Decides?" in A. W. Rovine (ed.), Contemporary Issues in International Arbitration and Mediation: The Fordham Papers 2010 (Brill, 2011), 70 (incoherence leads to unconstrained choice for tribunals). 
Abaclat and Others (Case Formerly Known as Giovanna a Beccara and Others) v. Argentine Republic, ICSID Case No. ARB/07/5, Dissenting Opinion, Georges Abi-Saab (28 October 2011) (*)

Abaclat and Others v. Argentine Republic, ICSID Case No. ARB/07/5, Declaration appended to the Award by Santiago Torres Bernárdez (29 December 2016) $(*)$

Adel A Hamadi Al Tamimi v. Sultanate of Oman, ICSID Case No. ARB/11/33, Award (3 November 2015)

AES Corporation and Tau Power BV v. Republic of Kazakhstan, ICSID Case

No. ARB/10/16), Award (1 November 2013) (*)

Alapli Elektrik BV v. Republic of Turkey, ICSID Case No. ARB/08/13, Award (13 July 2012)

Alps Finance and Trade AG v. Slovak Republic, UNCITRAL, Award (5 March 2011)

Ambiente Ufficio SpA and Others v. Argentine Republic, ICSID Case No. ARB/ 08/9, Decision on Jurisdiction and Admissibility (8 February 2013) (*)

Ambiente Ufficio SpA and Others v. Argentine Republic, ICSID Case No. ARB/ 08/9, Dissenting Opinion of Santiago Torres Bernárdez (2 May 2013) (*)

Apotex Holdings Inc. and Apotex Inc. v. United States of America, ICSID Case No. ARB(AF)/12/1, Award (25 August 2014) (*)

ATA Construction, Industrial and Trading Company v. Hashemite Kingdom of Jordan, ICSID Case No. ARB/08/2, Award (18 May 2010)

Bayview Irrigation District et al. v. United Mexican States, ICSID Case No. ARB(AF)/05/1, Award (19 June 2007) (*)

Biwater Gauff (Tanzania) Ltd v. United Republic of Tanzania, ICSID Case No. ARB/05/22, Award (25 July 2008) (*)

Caratube International Oil Company LLP v. Republic of Kazakhstan, ICSID Case No. ARB/08/12, Award (5 June 2012) (*)

Československá Obchodní Banka AS v. Slovak Republic, ICSID Case No. ARB/97/4, Decision on Objections to Jurisdiction (24 May 1999) 5 ICSID Rep 335

Deutsche Bank AG v. Democratic Socialist Republic of Sri Lanka, ICSID Case No. ARB/09/2, Award (31 October 2012) (*)

Deutsche Bank AG v. Democratic Socialist Republic of Sri Lanka, ICSID Case No. ARB/09/2, Dissenting Opinion of Makhdoom Ali Khan (23 October 2012) (*)

Enkev Beheer BV v. Republic of Poland, PCA Case No. 2013-01, First Partial Award (29 April 2014) (*)

Fedax NV v. Republic of Venezuela, ICSID Case No. ARB/96/3, Objections to Jurisdiction (11 July 1997) 5 ICSID Rep 183

Flemingo DutyFree Shop Private Limited v. Republic of Poland, PCA Case No. 2014-11, Award (12 August 2016)

Garanti Koza LLP v. Turkmenistan, ICSID Case No. ARB/11/20, Award (19 December 2016)

GEA Group Aktiengesellschaft v. Ukraine, ICSID Case No ARB/08/16, Award (31 March 2011) 
Giovanni Alemanni and Others v. Argentine Republic, ICSID Case No. ARB/ 07/8, Decision on Jurisdiction and Admissibility (17 November 2014)

Global Trading Resource Corp. and Globex International Inc. v. Ukraine, ICSID Case No. ARB/09/11, Award (1 December 2010) (*)

Helnan International Hotels A/S v. Arab Republic of Egypt, ICSID Case No. ARB/05/19, Decision of the Tribunal on Objection to Jurisdiction (17 October 2006) 17 ICSID Rep 258

HICEE BV v. Slovakia, UNCITRAL, PCA Case No. 2009-11, Partial Award (23 May 2011) (*)

Jan de Nul NV and Dredging International NV v. Arab Republic of Egypt, ICSID Case No. ARB/04/13, Decision on Jurisdiction (16 June 2006) 15 ICSID Rep 406

Joy Mining v. Egypt, ICSID Case No. ARB/03/11, Award on Jurisdiction (6 August 2004) 13 ICSID Rep 121

L.E.S.I. SpA et ASTALDI SpA v. République algérienne démocratique et populaire, ICSID Case No. ARB/05/3, Decision (12 July 2006)

Malaysian Historical Salvors Sdn, Bhd v. Malaysia, ICSID Case No. ARB/05/ 10, Award (28 May 2007) (*)

Malaysian Historical Salvors Sdn, Bhd v. Government of Malaysia, ICSID Case No. ARB/05/10, Decision on the Application for Annulment (16 April 2009) (*)

Malaysian Historical Salvors Sdn, Bhd v. Government of Malaysia, Dissenting Opinion of Judge Mohamed Shahabuddeen (19 February 2009) (*)

Marco Gavazzi and Stefano Gavazzi v. Romania, ICSID Case No. ARB/12/25, Award (18 April 2017) (*)

Mitchell v. Democratic Republic of the Congo, ICSID Case No. ARB/99/7, Award (9 February 2004) (*)

Mitchell v. Democratic Republic of the Congo, ICSID Case No. ARB/99/7, Decision on the Application for Annulment of the Award (1 November 2006) (*)

MNSS BV and Recupero Credito Acciaio NV v. Montenegro, ICSID Case No. ARB(AF)/12/8, Award (4 May 2016) (*)

Mr Saba Fakes v. Republic of Turkey, ICSID Case No. ARB/07/20, Award (14 July 2010) (*)

Nova Scotia Power Incorporated v. Bolivarian Republic of Venezuela, ICSID Case No. ARB(AF)/11/1, Award (30 April 2014)

Pantechniki SA Contractors \& Engineers (Greece) v. Republic of Albania, ICSID Case No. ARB/07/21, Award (30 July 2009)

Phoenix Action Ltd v. Czech Republic, ICSID Case No. ARB/06/5, Award (15 April 2009) (*)

Philip Morris Asia Limited v. Commonwealth of Australia, PCA Case No. 2012-12, Award on Jurisdiction and Admissibility (17 December 2015)

Pope \& Talbot Inc. v. Government of Canada, UNCITRAL, Award in Respect of Damages (31 May 2002) 7 ICSID Rep 148

Portigon AG v. Kingdom of Spain, ICSID Case No. ARB/17/15, Decision on Jurisdiction (20 August 2020) 
Poštová banka, a.s. and Istrokapital SE v. Hellenic Republic, ICSID Case No. ARB/13/8, Award (9 April 2015) (*)

Quasar de Valors SICAV SA, Orgor de Valores SICAV SA, GBI 9000 SICAV SA and Alos 34 SL v. Russian Federation, SCC Case No. 24/2007, Award on Preliminary Objections (20 March 2009) (*)

Romak SA (Switzerland) v. Republic of Uzbekistan, PCA Case No. AA280, Award (26 November 2009) (*)

RosInvestCo UK Ltd v. Russian Federation, SCC Case No. V079/2005, Award on Jurisdiction (1 October 2007)

RSM Production Corporation v. Grenada, ICSID Case No. ARB/05/14, Award (13 March 2009)

Saipem SpA v. People's Republic of Bangladesh, ICSID Case No ARB/05/7, Decision on Jurisdiction and Recommendation on Provisional Measures (21 March 2007) 17 ICSID Rep 352

Salini Costruttori SpA and Italstrade SpA v. Kingdom of Morocco, ICSID Case No. ARB/00/4, Decision on Jurisdiction (16 July 2001) 13 ICSID Rep 303 South American Silver Limited (Bermuda) v. Plurinational State of Bolivia, PCA Case No. 2013-15, Award (22 November 2018)

Standard Chartered Bank v. United Republic of Tanzania, ICSID Case No. ARB/10/12, Award (2 November 2012) (*)

Tenaris SA and Talta - Trading e Marketing Sociedade Unipessoal Lda v. Bolivarian Republic of Venezuela, ICSID Case No. ARB/11/26, Award (29 January 2016)

Tethyan Copper Company v. Pakistan, ICSID Case No. ARB/12/1, Decision on Jurisdiction and Liability (10 November 2017)

White Industries Australia Limited v. Republic of India, UNCITRAL, Award (30 November 2011)

Yukos Universal Limited (Isle of Man) v. Russian Federation, PCA Case No. AA 227, Final Award (18 July 2014) 18 ICSID Rep 331

\section{OTHER AWARDS}

Award in the Arbitration regarding the Iron Rhine ("Ijzeren Rijn") Railway between the Kingdom of Belgium and the Kingdom of the Netherlands, decision of 24 May 2005, XXVII UNRIAA 35

The Chamizal Case (Mexico v. United States), Award (15 June 1911) XI UNRIAA 309 